Portland State University

PDXScholar

1976

\title{
Oregon's Struggle Toward a Comprehensive Plan for Children's Mental Health Services: A Historical and Political Process
}

Kristin Angell

Portland State University

Follow this and additional works at: https://pdxscholar.library.pdx.edu/open_access_etds

Part of the Social Work Commons

Let us know how access to this document benefits you.

Recommended Citation

Angell, Kristin, "Oregon's Struggle Toward a Comprehensive Plan for Children's Mental Health Services: A Historical and Political Process" (1976). Dissertations and Theses. Paper 1808.

https://doi.org/10.15760/etd.1807

This Thesis is brought to you for free and open access. It has been accepted for inclusion in Dissertations and Theses by an authorized administrator of PDXScholar. Please contact us if we can make this document more accessible: pdxscholar@pdx.edu. 
OREGON'S STRUGGLE TOWARD A COMPREHENSIVE PLAN

FOR CHILDREN'S MENTAL HEALTH SERVICES:

A HISTORICAL AND POLITICAL PROCESS

\author{
by \\ KRISTIN ANGELL \\ A practicum submitted in partial fulfilment \\ of the requirements for the degree of \\ MASTER \\ of \\ SOCIAL WORK
}

Portland State University

1976 
The nembers of the Comnittee approve the practlcum of Kr1stin Ange11 presented August 2, 1976.
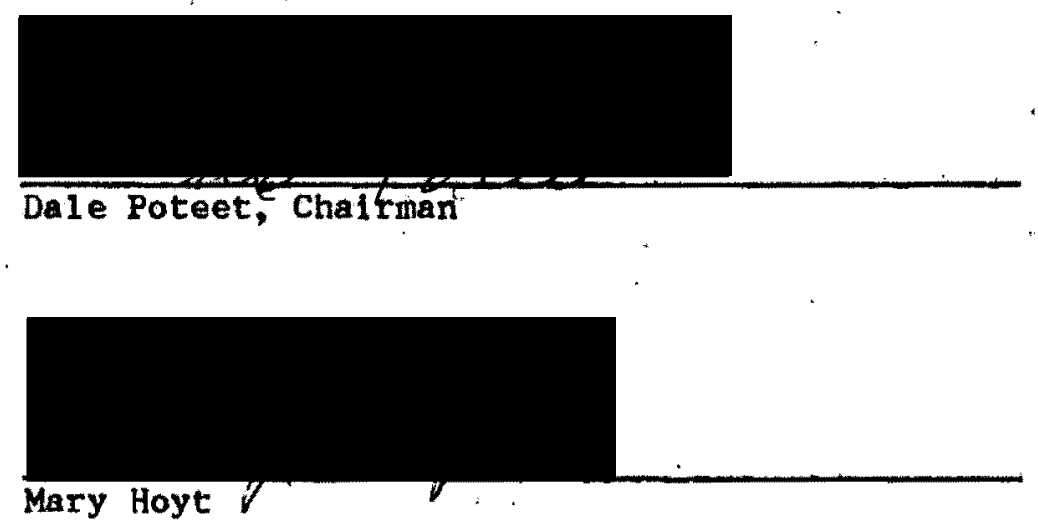
TABLE OF CONTENTS

PAGE

I IST Of TABLES .................... iv CHAPTER

I INTRODUCTION ................... 1

II OUTLINE AND METHODOLOGY ............ 5

III HISTORICAL DEVELOPMENTS ........... 7

Summary ................ 26

IV RECENT HISTORY AND CURRENT DEVELOPMENTS . . . : 30

V. NORTHWEST REGIONAL FORUMS ............. 41

VI PEDTATRICIANS AND THE CHILD MENTAL HEALTH

SYSTEM IN OREGON ................ 49

Characteristics of Study Population ...... 53

Magnitude of Problem ......... 55

Provision of Treatment and Use of Consultation . . 57

Utilization of Referral Resources...... 62

Satisfaction with Referral Resources . . ... 66

Summary ................. 71

VII PEDIATRIC TRAINING IN OKFGON .......... 75

VIII SUMMARY $\ldots \ldots . \ldots \ldots 4$ APPENกIX ........................ 88

BIBLIOGRAPHY ..................................... 121 
1 Percentages of Mentally and Enotionally

Disturbed Children Seen by Pediatriclans (1) . . .

II Percentages of Mentally and Emotionally

Disturbed Children Seen by Pediatriclans (2) . . ...

III Percentages of Children Treated versus

Those Referred ............. 58

IV Treatment versus Referral:

Measures of Central Tendency.......... 58

v Consultation Resources Used .......... 60

VT Preferred Resource for Pedlatrician's Family . . . 61

VII Referral Resources lised by Pediatriclans (1).... 63

VI.jI Referral Resources Used by Pediatriclans (2) . . . 64

TX Satisfaction with Referral Resources (1)...... 67

X Satisfaction with Referral Resources (2) ..... 68

XI Satisfaction with Training . ......... 81 


\section{CHAPTER I}

\section{INTRODUCTION}

Thls study first grew out of a happy meeting.

I first became interested in comprehensive planning for mental health services for children in oregon after attending the first N.W. Regional Forum on Mental Health Services for Chlldren in September, 1975. I had been previously interested in doing a historical analysis of the development of mental health services for children in this state, and the proceedings of the Regional Forum served to quicken my interest in current political process and Oregon's ongoing struggle toward comprehenisve planning for services. Shortly thereafter, I was introduced to Mary Hoyt and Tom Stern, members of the Child Study and Treatment Team of the Mental Health Division. Although they have been - and are - primarily involved in the planning and development of wental health services for children in the state, they felt that their efforts to mount an effective canpaign for funding in the next legislative assembly would be greatly alded by good historlcal perspective which would clarify not only the evolution of services in the state but would order and focus previous isolated attempts to study the problem. It was,. then, out of the confiuence of their need and my interest that I was motivated to integrate historical events with the current political process of planning.

My interest in pediatricians was stimulated in the early stages both of reading the historical 11 terature and study the comprehensive planning that was in progress. It seemed apparent from everything I 
was reading and hearing, that the formal network of mental health serylces for chlldren represanted only the tip of the 1 ceberg of all the services that were belng of fered to chlldren with mental and emotional problems. Under the surface was a vast system of caregivers professional and non-professional - who had significant contacts with this population of children but who often had 1ittle to do with the formal mental health system. I felt that no understanding of the efforts at comprehensive planning - elther as a curcent process or as the culmination of historlcal events would be possible without having some understanding of how these two "systems" Interacted. Once again my interest complemented some of the needs of the Child Study and Treatment Staff. One of the results of the Reglonal Forum was the development of a plan to mount a number of $10 \mathrm{cal}$ forums throughout the state withe purpose of gaining local input into the state planning process. They were, therefore, interested in any method which would give them information about such things as referral networks, satisfaction with mental health facilities, and ideas for improvements from some of the 1 ess visible caregivers who work with the mental health needs of children. In choosing a representative group to study, I considered school teachers, ministers, children services dividion workers, and pediatricians but finally chose pediatricians. My decision to focus on pediatricians was based on several things. First of all, the mental health information system for children suggested that they are a signiflcant source of contacts for the population of mentally and enotionally disturbed children. There was much in my reading and my own personal experience to suggest that for many families a pediatriclan is the first person who would be consulted for 
help with a troubled child. There were also many references in wy reading to the importance of pediatriclans to any kind of primary prevention program and to treatment programs which are based upon keeping the child in the community. While I found numerous studies and mention of programs deglgned to Improve all aspects of the relationships between schools and mental health workers, the relationshlp between pediatricians and the chlld mental health fleld appears to be little studied one. Defining the role of the pediatrician in both the existing mental health system and Oregon's evolution toward comprehensive planning is a complex one whlch involves at least four key questions: 1) What is the relationship of pediatricians in the state to the children defined as being mentaily and emotionally disturbed? How do they define the prob$1 \mathrm{em}$ ? Do they view themselves as important resources in dealing with the problem? If so, as therapists or diagnosticians? 2) What is the relationship of the pediatricians to elements of the formal mental health system which is set up to care for these children? How do they "use" the formal system? Do they make referrals freely and utillze consultation? Are they satisfled with the quality of the resources within the formal system which they have contacted? Do they have suggestions for improvement of the system? 3) What is the relationship of the formal system (a relfication in this case of people who work within the system) to these pediatricians? Are pediatricians viewed as an Importait resource - elther for planning or for providing care by those involved in comprehensive planning for the state? 4) How is the role of the pediatrician within the mental health network belng defined by those in charge of training pediatriclans in the state, namely, the Unlversity of Oregon Medical School pediatric residency 
program? How are pediatric residents trained in speciflc content areas of child mental health and childhood psychopathology? Do they recelve any training in using consultation or making referrals to mental health resources? Are residents satisfled with the training they recelve in these areas? Is there any evidence of changing philosophy within the department vis a. vis mental health issues? Obviously, the aniswers to these questions lead to the final question of what role - If any - the pediatriclans are playing (or should be playing) in helping to shape the ultimate form of Oregon's comprehensive state plan for Children's Mental Health Services. 
OUTLINE AND METHODOLOGY

History and political process are the twin sisters which wust be consulted to gain any understanding of a present event. Trying to understand a polltical event without understanding its history leads to a tunnel vision as 1 mited as that of a practitioner trying to assess the functioning of a client without any knowledge of his background. Looking at history without bearing in mind its relevance to current dynamlc process and events is, on the other hand a 1 ifeless exercise at best. In clinical practice, it would be akin to the orror of attending only to a client's history without observing his present behavior or looking at the context of his immediate social systems. Past and present fuse in the systems of a state no less than in those of an individual. With this interaction in mind, I will divide the chapters evenly between those devoted to the history and background of the children's mental health movement in oregon, and those devoted to a specific examination of the position which pediatrictans occupy in the state. Chapter III will be concerned with a broad overview of Oregon's history up until the early 1970's. It will inciude a brief synopsis of the major studies and documents which have contuributed to an understanding of chlldren's mental lilness and the development of systems to care for them in this state. Chapter IV will look at more recent developments in the state and 111 include some integration with trends whlch are occurring nationwide. Chapter $V$ will be devoted to a rather extensive analysis of reglonal and local fortms, which have played a major part in the developmerits of the last year.

Chapter. VI w11 present a proflie of the pediatrictan in Oregon. 
It w11 chiefly concern an analysis of a questionnalre sent out to all the pedlatricians in the state. A more extensive discussion of methodology will be Included in that chapter. Following this, in Chapter VII, wi11 be a look at the pediatric training program in Oregon - as it relates to child mental health issues and will be based largely on intervlews done with the staff and questionnaires sent to residents of the training program. Finally, Chapter VIII, the concluding one, will draw some conclusions and will of er some final speculations about directions which the child mental health movement may take in oregon: 


\section{HISTORICAL DEVELOPMENTS}

Oragon's history of treatment of the mentally 111 - whether children or adult - begins in 1844, fifteen years before its formal admission to the union. In this year the provisional territorial legls1ature appropriated $\$ 500.00$ "for purposes of defraying expenses of keeping limatic or insane persons in Oregon." 1 Under the provisions of this grant, any justice of the peace had the authority to use this money to contract the care of any insane person to the lowest bidder. In 1849, the first Territorial Legislature adopted certain acts from the revised statute of the Territory of Iowa (1843), which included two acts pertaining to the care of the insane. According to them, the Insane indigent were entitled to all the provisions of the poor law, and secondly were to be the special charge of the "overseers" who had the authority to arrest or confine them. Such overseers were not appointed, however, unti1 1851 when the second territorial leglslature established boards of county commissioners in each of the elght counties then existing. ${ }^{2}$ It is interesting to note that this period in Oregon's early history roughly corresponds to the period of sweeping reforms for care of the mentally 111 on the eastern seaboard under the stimulus of Dorothea Dix and her hospltal reform movenent.

In 1862, the Oregon Legislature enacted a statue directing the governor to contract with a sultable person or persons to care for insane or ldiotic persons. The county courts, with the ald of one or more

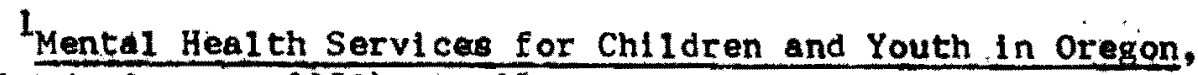
(Portland, Oregon, 1950), P. 12

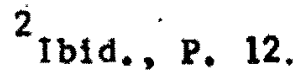


physiclans were to make this commitment, but only in the case that friends or relatives were unable to care for the insane Individual. ${ }^{3}$ A Dr. Hawthorne in Fortland recelved a great many of these persons and continued to operate a private institution in Portland for 20 years until mounting criticism of this "contract system" led the state legislature in 1880. to authorize the construction of a state insitution for the care of the insane. 4 This building was completed in 1883 in Salem, and subsequently, a second state institution was built in Pendleton in 1913. These early periods of Oregon's history are described by one historian as: 1) Laissez faire (1850's) 2) farming out (1860's) 3) private institutional care (1868) 4) state custodial care $(1882)^{5}$

Although the establishrent of the first juvenile courts and beginning studies of psychologists at the end of the 19 th Century led to the first clinical psychological services for children, there were no separate facilitles for childeen during the flrgt 60 years of oregon's history, and indeed, during this period the mentally retarded and insane wore treated together as well. In the year 1907, however, the state legislature authorized the construction of apecial institution near Salem for "feeble-minded and epileptic children," which has been in use

$$
\begin{aligned}
& 3 \text { Ibid, P. } 12 . \\
& { }^{4} \text { Ibid., P. } 13
\end{aligned}
$$

${ }^{5}$ Chlld Guldance in Oregon: wth Recommendation of the Governor's Specla1 Committee, University of Oregon Medical School, (July 1, 1937), P. 23. 
since that time and is now known as Fairvier State Hospital. 6

In 1915, a Dr. DeBusk, professor of education and clinical

psychology at the University of Oregon, conducted numerous lectures

around the state on mental hygiene toplcs. This stimulated considerable interest in this area which then proliferated into the mental hygiene movement which continued actively through the decade of the 1920's. 7 Some of the activity during this period included a "Mental Hygiene Survey of Multnomah County," in 1921, secured by Dr. D11lehunt, then Dean of the Medical School, a study section on child development for parents sponsored by the American Association of University Women, active parent-teacher groups, and the early Mental Hygiene Association progenitor to the present Mental Health Association, which existed from 1920-24. During this time, Dr. DeBusk was receiving school referrals for problem children and his encouragement was instrumental in the development of school psychologists and social workers. 8

Dr. DeBusk's contributions were greatly amplifled by developments which were going on nationaliy. In 1922 a five-year program of demonstration clinics, sponsored jointly by the commonwealth fund of New York and the National Comnittee for Mental Hygiene furnished a prototype of the present Chlld Guldance Clinic. In 1925 another demonstration grant establishad the services of social workers in 30 schools nationwide. At

Gental Health Services for Chlldren and Youth in Oregon, (Portland, Oregon, 1950), P. 13.

$7_{\text {Ibid.; P. } 13 .}$

8 Ibid., P. 15. 
that time Gladys Hall, a soclal wotker, directed those sorvicia in

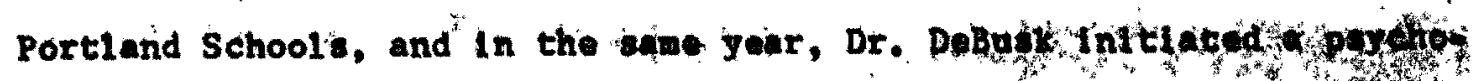
educational clinle in the achools.?

Op unt11 th1 s tine the development of wental heal th sogktees for children had largely been shaped by the peychologlcel and dablityotk services which had grown in close assoclation with the schoofly. If 1929, however, the University of Oregon Medical School opened Its Department of Psychiatry. 10 Another Important developitent firpiy ontabliahed the medical flelds as another professional disclpline thich would have a major irituence on the subsequent history of mented hearth fervtops for children In Oregon. In 2931 the Univerity of Oregon Megtical School sponsored "travelling clinl ca" which oftered diagnostic services

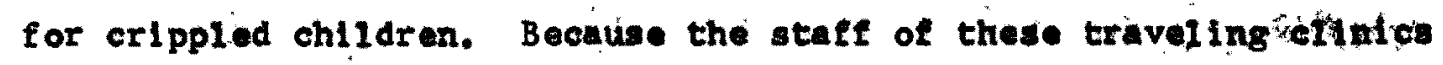
were so often consulted by $10 \mathrm{cal}$ agencles and private physiafins for help in dealing with the enotional problens of children brought to the c1intes, eventually psychiatri sts vere invited to join thie achef of this traveling team.

The confluence of these developments, then, led to the consplidation of communtey based mental health programs for children the the

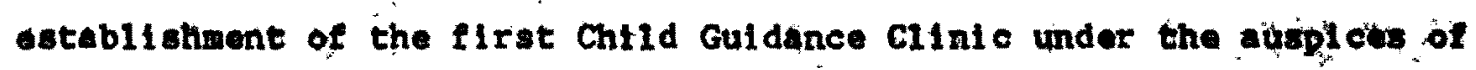

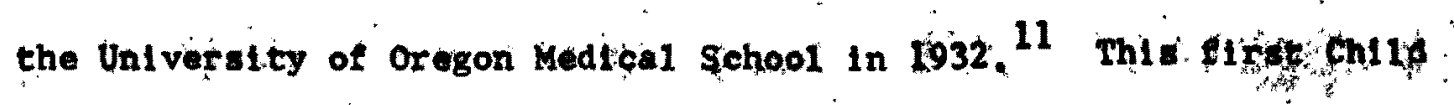

Mental Heil th Services for Ch11dren and Youth in Oregon, (Portland, Oregon, 1950), P. 17.

10.Child Guidance in Oregon: th Recomiendation of the Governor's

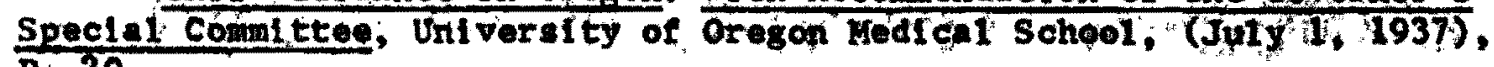
P:20.

11 The Ultimate Goal: A Plan for Today A Comprehensive Plan for a Mental Health Progran in oregon (Saleh, Oregon State boatd of Controi, 1965) P. 4. 
Guldance Clinic, which was housed in Doernbecher Hospltai, offered 2t days. a week service to chlldren referred by the Juvenlle Court, the school, the Pediatic Clinic of the University of Oregon Medical School, and other child caring agencies. As first established, the Child Guidance Clinic was to correlate "medical psychological and social phases of chi1d problems." Pursuant to this goal, the core staff was made up of a psychiatrlst, a psychologist, and a soclal worker. A team approach which has remalned traditional up to the present. As can be seen from the diagram in Appendix $A$; both the contributlons and the basts of support for the Child Guldance Clinic cut across many agency and professional lines and was viewed as a broadly based communty program. This. goai of multiple impact is echoed in a document, entitled Child Guldance In Oregon, which was published in the 1930's and which 12id out at great length the early philosophy and goals of the child guidance movement in Oregon: "Utilization of a Guldance Clinic... In the adjudication of juvenile court problems, in the disposition of wards of the court and treatment thereof, and in the study of public school chlldren exhibiting probiems of conduct will have far reaching social benefits to the state." 12 The theme of "benefits to the state" was a slgnificant one in the 1930's. The optimism which had been generated by the clinical applications of child psychiatry in the Child Guldance clinies combined with the increasing attention patd to such things as cost factors led to a new belief in preventive psychlatry which prevalled through the $1930^{\prime} \mathrm{s}$. Indeed, it is significant that in 1932, the same year as the founding of

${ }^{12}$ Child Suldance in Oregon: with Recommendation of the Governor's Special Comnittee, University of Oregon Medical School, (Ju1y 1, 1937), 
the first Child Guidance Clinio, the first Oregon White House Conference on Chlld Health and Protection was held. In the keynote speech, reference was made to prevention of mental disorders as one of the most "promising means of reducing pub1 ic expense." 13 ' In this early. period, the Child Guldance Clinics were seen as the cornerstone of preventive psychlatry. In the very small section on Mental Health Services for Chlldren in the 80 page document generated by the 1932 Oregon White House Conference, the only recommendation for any specific program states that in order "to develop an adequate plan for preventive psychiatry, it will be necessary to extend the services of the Child Guidance traveling clinics."14 The rest of the section makes f requent but vague references to the importance of establishing adequate state services. In 1937 the state Leglslature passed the "Child Guidance Extensi on Act" and appropriated $\$ 24,000$ for the Child Guidance Extension Services, including the traveling clinics. 15 The same committee which sued for extensi on of the Child Guidance clinic reconmended a law "providing for adequate physical and mental examination of men and women applying for 11 censure for marrlage, with a view to preventing the production and propagation of the mentally unfit, as

${ }^{13}$ Oregon'g White House Conference on Child Health and Protection (Salieal May 1932), P. 11.

14 Ibid., P. 65

15 The Ultimate Goal: A Plan for Today A Comprehensive Plan for a Mental Health Program in Oregon (Sal em, Oregon State Board of Control, 1965) P. 4 . 
well as preventing transmission of the disease."16 As a historical. artifact, it provides a fascinating gilmpse of the extent to which the state tried with a noteworthy lack of success to take responsibility for preventive psychlatry during this era.

During the $1940^{\prime} \mathrm{s}$, the Child Guldance Clinic, as the focus of Child Mental Health Services gradualiy shifted. The demand for services from the many agencles Involved with the Child Guidance C1inic had increased enormously. At the same time, the University of Oregon Medical School had committed more and more of Its resources to the traveling clinics without appreciably expanding the community services it offered. In 1944 the Council of Social Agencles in Portland carrled out a survey of local needs for mental health services for children. As a result of their recommendations and Increasing public interest, the first community Child Guidance Clinlc was organized and first opened in 1947 , supported by funds from the Community Chest. 17 Under the directorshtp of Carl Morrison, a child psychiatrist, the center poovided consultation, diagnostic and treatment services and also community education. A1so in the year 1944, Milton Kirkpatrick, from the National Committee for Mental Hyglene, who had authored a book in the $1930^{\prime} \mathrm{s}$ on the Child Guldance Movement in Oregon did an evaluation of the traveling cilnics. 18 This stimulated further the interest in chlld psychiatry issues at the University of Oregon Medical School, but vould probably

${ }^{16}$ Chlld Guldance in Oregon: with Recommendation of the Governor's Spec $\{1$ 1 12 .

17 Heal th Services and Facillties for Children in Oregon (Portiand, Oregon, 1952) P. 56.

${ }^{18}$ Mental Health Services for Children and Youth in Oregon, (Portland, Orégon, 1950), P. 16. 
not have resulted in any significant changes had it not been for the passage in 1946 of the Federal Mental Health Law. As a result of this law, federal money became avaliable, most of which was used in Oregon to stimulate mental health services for chlldren. The Public Health Department was the officially designated authority for dispersing these funds. In 1948, the availability of these funds mde it possible for the traveling clinics to recelve a full time child psychiatrist as its director. Thenceforth, the old traveling clinics became known as. "Oregon Psychiatric Services for Children." 19 In addition to the traveling clinics, which visited elght population centers in oregon, the responsibilities of the OPSC also included: 1) full time clinic at the University of Orogon Medical School with an emphasis on evaluation, consultation and referral and 2) teaching of students, interns, nurses, and other house staff at the University of Oregon Medical School in child development and psychology. ${ }^{20}$ As a result of these developments, the Child Guidance Cilnic at the University of Oregon Medical School was discontinued. While the OPSC continued a collaborative relationship with the Community Child Guidance Clinic, the effect of this separation was probably to separate the Medical School Increasingly from the commity and to consolidate its speclalized role as a training center for chlid psychiatry. At the same time uncer the stimulus of the money avallable from the 1946 Mental Health Act, other $10 \mathrm{cal}$ mental health programs were being developed so that by the late $1940^{\prime} \mathrm{s}$, at least six countles had active mental health clinical programs for children. Most of them

19 Health Services and Facilitles for Children in Oregon (Portland, oregon, 1952), P. 55 .

20 Mental Heal th Services for Children and Youth in Oregon, (Portland, Oregon, 1950), P. 19. 
used the consultation services of a psychiatrist and were federally supported. 21

By the late 1940's and ear1y $1950^{\prime} s$, concern for the mental health needs of children led to a series of studies and meetings aimed at defining the health and mental health needs of chlldren. In 1948 the American Academy of Pediatrics directed a study titled Child Health Needs in Oregon containing a section describing mental health services in the state. Although this study made no specifle recommendations for mental health services to children, another report expressed concern that no other hospltal in Oregon besides Doerenbecher at that time provided any organlzed consultation services to the pediatric staff for children with problems related to their emotional status or mental development. 22 By 1950 generai interest had proliferated to such an extent that a Governor's State Conference on Children and Youth, held in that year drew 1,100 professional and lay people from $a 11$ over the state, and the concerns expressed at that conference indicated an increased awareness of the need for Improved mental health services to children. ${ }^{23}$ Expansion of these services to chlidren was advanced on several fronts durIng the 1950's. By 1953, local programs had developed so much that in that year the traveling clinics of the OPSC were discontinued, and the years between 1953 and 1962 saw the development of 11 child guidance clinics. 24 Throughout the 1940's and 1950's services for children in.

21 Mental Health Services for Children and Youth in Oregon, (Portland, Oregon, 1950), P. 25.

22 I bid., pp. $29-30$.

23 Ibid., P. 41.

24The Ultimate Goal: A Plan for Today A Comprehensive Plan for a Mental Health Program in Oregon, (Salem, Oregon State Board of Control, $1965)$ P. 5. 
the schools had taken the form of the "visiting teaching department." Since the days of Gladys Hal1, the department had continued to expand, so that by 1950 there were 14 psychiatric soclal workers who worked in 40 ementary and $8 \mathrm{high}$ schools acting as consul tants to teachers and lialson personnel between school and mental health agencles. Although the decade of the 1950 's witnessed the formation of numerous committees and stiudles around the needs of children and the publication of no fewer than five major state documents on needed services for children in the state (See Append $1 \times$ B), there was already evidence of a fragmentation of programs and conflicting recommendations at the state level. In 1950, the most extensive document on mental health services for chlldren in the state up to this time concluded its report with the conviction that simple expansion of direct service resources could never be the answer to the lncreasing needs of children. It recommended, instead the concentration of resources on teaching, consultation, and coordination of services. 25 In a Sumary of Reports to the Governor from a thite House Conference on Needed Services for Children in 1959, the recommendations to the governor included needed public welfare services for children, needed services in education and recreation for chlldren, but nothing speclfically on the mental health needs of children. 26 on the other hand in the same year, the Oregon Governor's State Committee on Children and Youth in its complete report to the Golden Anniversary White House Conference on Chlidren and Youth made the following specific recommendations under the section on Health:

25 Mental Health Services for Chl1dren and Youth in Oregon, (Portland, Oregon, 1950), P. 46.

${ }^{26}$ A Needed Service for Oregon's Children: A Summary of Reoorts, (Sal em, Oregon, 1959) 
1) Continued emphasis on the education of non-psychiatric people working with children: "such tralning can result in a creditable job trom such persons in the field of preventive health work."

2) School social work should be developed.

3) Support the establishment of a school of social work.

4) Outpatient facilities for the diagnosis and treatment of mentaily ard emotionally disturbed and mentally retarded chlldren, should be developed at Eastern Oregon State Hospltal.

5) Immediate and thorough study should be made in the area of mental health, particularly to define and determine the problems of emotional disturbance. The study should result in planning responsibility and in recommending comprehensive solutions rather than a piece-meal approach. 27.

Tt can probably be said safely that this increasing awareness of the need for a tighter organization of expanding services 1 ed to a decade of planning and organization of mental health services that was more intense than any period in oregon's history. The keynote had been sounded in the final recommendation of the foregoing conference. In late 1959 the Governor appointed a committee called the "Governor's Mentai. Health Advisory Commlttee," giving it the task of studying mental health services throughout the state and making speclfic reomimendations for an improved mental heal th program. As a direct resut of their. report, In 1961 the Mental Health Division was created under the super-

27 A Look at Oregon's Children: Report to the Golden Anniversary White House Conference on Children and Youth, (Salem, Oregon, Nov, 1959), pp. 73-74. 
vision of the Oregon state Board of Control. ${ }^{28}$ The years of 1961 and 1962 were active ones nationally, as the Kennedy Administration committed considerable resources to studying the problems of the mentally retarded and emotional1y disturbed. In 1963, Iandmark leglslation passed, creating the Comprehensive Community Health Centers Act. The passage of this act had several effects. First of all, the availability of federal money stimulated the rapld development of new mental health programs. Secondly, it mandated comprehensive planning and tighter organization of mental health programs, With its emphasis on alternatives to hospitalization, it launched the romance with community mental health programs which continued into the 1970's. If in retrospect, the philo- ; sophy behind this movement seems overly optimlstic, it nonethel ess, had an undenlably benlgn influence in encouragtng state planners to think in terms of total community systems rather than isolated treatment el ements.

As was seen, Oregon already had considerabie momentum toward reorganization and planning that fust recelved further reinforcement from the passage of the Act in 1963. For children's programs, some of the most 1 mportant documents produced in Oregon came out of the six year perlod following this from 1964-1970. In 1964, Eugene Taylor, a child psychiatrist in Portland, published his now famous report, Needed Services for Severely Emotionally Disturbed Children In Oregon. This report included an extensive survey of many professional sources to determine the extent of children in need. While he eschewed trying to

28 The U1timatte Goal: A Plan for Today A Comprehensive P1an for a Mental Health Program in Oregon (Silem, Oregon State Board of Control, 1965), P: 5 . 
obtrain preclse figures on the numbers of emotionally disturbed children In Oregon, he was nonetheless able to make Intelligent estimates based on comparative data from other states and from the rough figures gathered from the questionnaires he sent out. In addition to soliciting data on prevalence and incldence, he also Invited ideas for planning residential treatment from the Mental Health Planning Boards of all 50 states. It is a noteworthy study in the care that it takes to avoid generalizations or hasty conclusions in any area. He takes extreme care to discriminate not only variations in severity but in types of disorders with their differing treatment needs. Besides his more specific recommendations, Taylor urges that mental health clinics take a leading role in the development of Intensive treatment services for chlldren, including consultation to other agencies. 29 since they provided the basis for so much subsequent program planning, his reconmendations for treatment spaces is quoted in full below:

\begin{tabular}{ll}
320 & $24-h o u r$ residential hospltal beds \\
400 & Day treatment spaces \\
110 & Therapeutic nursery spaces \\
165 & Therapeutic foster fanlly spaces \\
210 & Special home help spaces \\
\hline 1,205 & Total 30
\end{tabular}

Even though speciftc numbers have changed and some information is outdated, It is a study undertaken with enough care and sophistication to make it remain a princlple resource document for all of the state pianning that has been done around the needs of emotlonally disturbed

${ }^{29}$ Eugene Taylor, "Needed Services for Severely Emotionally Disturbed Children in Oregon," Unpublished Report to the Mental Health Planning Board, (August 1964), P. 3 .

${ }^{30}$ Ibld, , P. 
children since that time.

In 1963 , several developnents were taking place in the state. In Portland, a comittee of staff from the University of Oregon Medical School formulated recommendations for a training, research and service program at the Medicalischool in the fleld of children's emotional and developmental problems; Ultimately, a separate department of child psychiatry was started At the state Level, a mental hedth planning committee was formed with the ald of a one year grant from the National Institute of Mental Hekith for the purpose of writing a comprehensive state plan for mentai health services. The results of the comittee's work vere published in The Ultimate Goal, A Plan for Today, which appeared in 1966. This comprehensive plan has been to the total mental health program in Oregon what the Taylor Report was to mental health prograns for children. Even though it is ten years old, it is stil1 probably the most complete and advanced piece of comprehensive planning that exists for Oregon. Its section on comprehensive planning for chlldren's serviceps draws heavily on the Taylor Report, and is probably consulted more frequently than the latter because of its concise overview of needs andírecommendations. One singular contribution it makes stands like a warning of a trend in the state which becomes more pronounced by the early $1970^{\prime} \mathrm{s}$. It provided a thumbnail analysis of services avaliable to children compared to those available to adults at that time: 


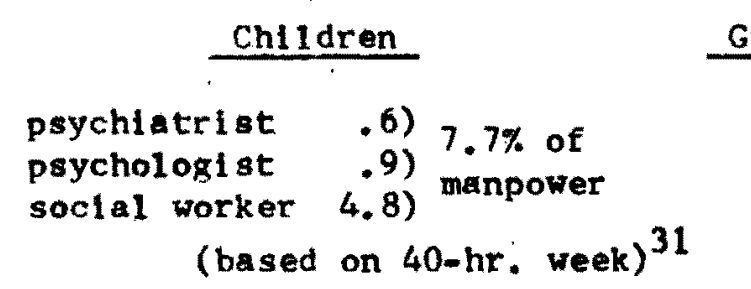

Group I-III Adults (mi1d-moderate Impeit raent).

17) $77 \%$ of

19) manpower

In the several years following the Comprehensive Community Health Centers Act and the State Comprehensive Plan, concern was mounting In several quarters about the Increasing gap between service need and servlce availability for children. In splte of the novenent toward community based programs, at least three different publications pointed out that unl1ke most states, which have at least two types of services, Oregon ralled largely on a Child Guidance System without ever developing a separate hospltal facility for its severely disturbed children. Consequently, it was the opinion of several people in the Mental Health Division that at the time, that constituted the area of greates need. In a report dated Apr11, 1966, titled A Residential Care Program for Children and Adolescents with Severe Mental I1lness, Joe Treleaven, M.D., outilned'in detail his recommendation for a 42 -bed intensive treatment. children's and adolescent's unit, to be housed at the oregon state Hospltal. 32 it is noteworthy that central to his plan were the proposed concomitant developments of community based facilities which would operate together: with the unit. This would have involved the development of a variety of community services and would, in his vien,

31 Eugene Taylor, "Needed Services for Severely Emotional1y Di sturbed Ch11dren In Oregon," Unpub1 I shed Report to the Mental Health Planning Board, (August 1964), P. 35.

32 J.H. Trel eaven, "A Residential Care Program for Children and Adol escents in Severe Mental IIIness," Monograph (Apri1 13, 1966), P. 
have reduced the expense and disadvantages of trying to provide 320 residential treatment spaces recommended by Taylor. Treleaven's recommendations were adopted in a section on needed programs for chlldren which appeared in the officlal Mental Health Division Review of Mental Hea1th Programs in December, 1966. Also in this report there appeared the observation that services provided by the Community. Mental Health C11nic's between the years 1964-65 and 1965-66 increased marked1y with the exception of services provided for children which showed a drastic decrease for that period (from $53.5 \% \quad 42.6 \%$ ). 33

In spite of the fact that in 1965, the National Instl tue of Mental Health had published a small book describing research findings, research goals and programs for children in need of mental health services at every level of prevention, currently supported by the chi1d program of the National Institute of Mental Health, there were numerous indicators that children were not sharing equally in the wave of new programs and services stimulated by the 1963 Federel Leglsiation.

The appearance of a small report in Apr11, 1967 titled Draft of Purchase of Care Program: Psychlatrlc Services for Chllaren put out by the Mental Health Division amounted chiefly to an extension of Treleaven's recommendations for an inpatient hospital orlented diagnostic, evaluation, and short term treatment facility. As such, it added 1ittle in the way of planning for chlldren's programs. It did offer a brief review of faclities newly avallabie for children which had not been included in previous reports and also placed the importance of the comminity in perspectlve by urging that definite follown

33"Rieview of Mental Health Division Programs," Mental Health Division, Unpublished Report, (December :15, 1966), 
care by a geheral practitionec or pediatrician by mandatory, indeed, a condition of acceptance into the program. ${ }^{34}$ The emphasis of the recomimendation also differed slightly from those offered by Treleayen insofar as they urged that any such inpatient faclilty be housed some place other than at the State Hospital. This difference in opinion is interesting In 11 ght of the conflict that was to be activated in $1974-75$ over the location of the children's and adolescents' secure treatment unit. Following the Taylor Report, it was not until 1968, that a major contribution was made to the development of children's programs in the state. In that year a special commlttee delegated from the office of the Governor mounted a massive study of children's welfare needs in the State of Oregon, the so-called Greenleigh Report. It is striking that In this vast compendium, the section on the mental health needs of children is 1 imited to seven pages, as the committee. concluded that this was one of the areas that had already recelved adequate study in the Taylor Report and The Ultimate Goal. It concluded this section by offering four recommendations:

1) 24-hour intensive care be made available

2). A therapeutic foster care program

3) Development of special classes

4) Separate state hospltal facilities for children 35

34"Draft of Purchase Care Program Psychlatric Services for Children," Unpubilshed Report, Oregon Mental Health Division, (April 1967), P. 6.

${ }^{35}$ Child Welfare Needs and Services in Oregon (New York: Greenlelgh Associates; Inc.; December, 1968); P. $_{30 .}$. 
In concluding its discussion on the extent of the problem in Oregon, the commlttee observed that by the most conservative estimate, barely half of the children needing psychiatric services were recelving 1 t $^{36}$ They went on merely to say that while the demand for services on the Mental Health Centers was enormous, there seemed to be consensus amoung the various agency professionals in the six counties surveyed that an expansion of clinic services was an indispensable pant of meeting the needs of children in the state. 37 It is an ironic footnote to this recommendation that in the perlod between $1966-67$ and $1967-68$ the Community Mental Health cilinics recorded a further orop in services provided to children, from 6,425 to $6,390 .^{38}$

The same year which witnessed the publication of this masive report saw an Important development in Children's Programs in the state take place.' In 1967, the Fifty Fourth Legislative Assembly passed House B 111 2104. In Chapter 455 of that Act, the Mental Health Division was authorized to set up a two year pllot program "to provide services for emotionally disturbed children and to conduct research to determine the nature and extent of services required for such children in the state." 39 As an integrated approach to the needs of emotionaliy disturbed children in the state, the program represented

${ }^{36}$ Child Welfare Needs and Services in Oregon (New York: Green1 elgh Assdclates, Inc., December, 1968), $\frac{1}{192}$.

37 Ibld., P. 195.

38"Pilot Program for Emotionally Disturbed Children," Unpublished $\frac{\text { Report, }}{\text { P. } 3 \text {. }}$,egon Mental Health Division, (Salem, Oregon, February, 1969),

${ }^{39}$ See Oregon Legislative Assembly: 1967 Regular Session, House B!1I 2104 , Ch. 455 , Sec. 2 . 
something of milestone. Those in charge of cargying out the program questloned the usual approach of seeking solutions in the building of new faclities. Instead, it sought a new approach which might be said to emphasize such things as integration, co-ordination, moblizization, rather than expansion or Innovation. The philosophy behind the goals of this program is striking enough to merit quotation in full:

"The Pllot Program for Emotionaliy Disturbed children... Is not designed to supplant existing facllities, nor is it designed as quick treatment technlque. It is an attempt to locate and Identify the chlldren who need services. It might be considered a flexible adjunct to evaluating and programing for these children as close to their natural setting as is possible.

"This report is not a solution to the need for comprehenaive mental health services; but it aims to establish guidelines for the economical use of professional time to explore techniques of short term placement and integration of community facilities. It Is also an attempt to evaluate the effectiveness of a technique which makes use primarily of existing facllities rather than directs (sic) itaelf to the construction of new facilities." 40

Central to the Implementation of these goals was the operation of the Child Diagnostic Center housed at Edgefield Lodge in Portiand. The varlous elements included a four week intensive residential diagnostic perlod for children under 12 years old; concurrently an indepth assessment of all the elements of the child's ecosphere, including the family (who was sometimes included in the residential diagnoștic program), potential and actual service resources in the community and all agencies previously involved with the problem, and finally an aftercare plan thich involved contracts with aftercare agencies, consultation with key community resources through the 1 ialson workers, and followup reports. In Oregon's history, the program was unique in that it offered - both conceptualiy and operationally - a

40"ipilot Program for Emotionally Disturbed Children," Unpublished Report, Oregon Mental Health Division, (Salen, Oregon, Febraary; 1969), P. 4. 
system deslgned to coordinate an intensive diagnostic program into a network of congultation and aftercare services within the commity. Although the services offered by the program only included those children under 12 years old (in its search for a contract agency, the program had found no single facllity capable of meeting the full range of service demands for all children under 18), the progran was able to report to the Fifty Fifth Legislature that in the 20 months of its operation, the center had admitted 78 children, with 700 requests for servlce and a usual waiting perlod of three months. 41 In some ways, it was a program ahead of its time. Although the Mental Health Division included a recommendation for continuation and expansion of the program in Its 1969-71 budget request and despite Chapter 254 of Oregon Laws, 1969, which.repealed the termination date, with the obvious legislative in. tent to continue the program, the Child Diagnostic Center was terminated in June, 1970 because of budgetary deficiency in the Mental Health DIvision.

\section{SUMMARY}

In many ways, the closing, of the decade of the $1960^{\prime} \mathrm{s}$ was a benchmark period in the development of children's programs in the state, and the perlod which followed it is deserving of a separate chapter. Before turning to the developments which have occurred since 1970, however, it would be well to take a fresh look at some of the developments which set the stage for the accomplishments - and stalenates - of the

41"pliot Program for Emotiona11y Disturbed Children," Unpublished Report, Oregon Mental Health Division, (Salein, Oregon, February, 1969), P. 20 . 
1970's. On the Federal level, the nation had gone through the agoni es of watching mental health programs recelve an optinistic boost from the Kennedy and Johnson Administrations only to see infant programs collapse under th conservative domestic policies of the Nixon Administration. At the state level, oregon had done considerable reorganizing in the mental health field. Concern about the increasing fragmentation of services had led to the consolidation of responsiblltty for programs with the creation of the Mental Health Division In 1961. Childmen's needs were much studied and discussed; so much so, in fact, that a member of the Portland City Club was prompted in 1971 to remark that, "Oregon may well be the best documented state in the nation as to prevalence and needs for treatment of emotional disturbance in chł1dren. "42

But what actually happened to mental health services for children during the ten years between 1960 and 1970? The timing of the Taylor Report in 1964 seemed calculated to ensure that the wave of interest in mental henlth programs following the passage of the Federal Comprehensive Community Health Centers Act of 1963 would not overlook the pressIng needs of children. Indeed, the expansion of mental health centers continued to be mentioned hopefully as a possible answer to those increasing needs. Yet, for a variety of reasons, Oregon remalned shy of involvement with either Federal guidelines'or Federal noney and largely rejected the Comprehensive Community Health Centers Act model. Oregon's own comitment to expansion of mental health services in the Comprehensive Commity Health Centers left chlldren, sadly in the lurch, so that

42 "Report on Services for Severely Disturbed Children in Oregon," Portland Clty Club Foundation, Inc., Vol. 51, No. 42 (March 19, 1971), (Porclitid, Oregon), P. 284; 
by 1970 , services provided to children by the Comprehensive Communtty Health Centers had shown a steady decline. The Greenlelgh Report, published toward the end of the decade, gave short shrift to mental health needs of children, primarily relterating the estimates of need and recominendations for service which had appeared in previous reports, Taken as a totality, however, the Greenlelgh Report documented the sadiy fragmentary character of services which radlated through dozens of care glving agencles and were robbed of a great proportion of their efflcacy because of the lack of any single coordinating agency wose sole responsibllity was the total well-belng of chlldren. Yet, as has been seen, Oregon was not lacking in intelligent and committed advocacy for children. The Taylor Report represented one of the most careful and thoughtful studies on the needs of the emotionally disturbed child done anywhere. Yet, while the study remains quoted up to the present day, the urgency of the recommendations has seemingly had 11 tele effect on the development of services for children. The Pllot Program for Emotionally Disturbed Children was striking for its innovations in a comprehensive systems approach. Yet the program was funded only the soft money avallable from a two year demonstration grant, and when the program was cut back at the end of the two year perlod, many of the trained personnel and the hard-earned co-ordination of resources was lost. Once again, those committed to chlldren's programs were forced to patch together services plecemeal in an effort to salvage some of the gains. It must not have been encouraging to the workers of this perlod to see such negative goals usher in the 1970's. Indeed, they mlght well have echoed the warning and recommendation that concluded the decade of the 1950's: 
"The study should result in placing responsiblitity and in recommending comprohensive solutions rather than in a plecemeal approach."

43"Report to' Golden Anniversay W.H. Conf, on Children and Youth;" Oregon W. H. Conference, (1959), pp 73-74. 


\title{
RECENT HISTORY AND CURRENT DEVELOPMENTS
}

\begin{abstract}
"This Nation, the richest of all world powers, has no unifled national commitinent to its children and youth. The claim that we are a child centered soclety, that we look to our young as tomorrow's leaders, is a myth. Our words are made meaningless by our actions - by our lack of nationai, community, and personal investment. in maintaining the heal thy development of our young, by the miniscule amount of economic resources spent in developing our young, by our tendency to rely on a proliferation of simple, onefactor, short-term and expensive remedies and services. As a tragic consequence, we have in our midst millions of 111-fed, 111-housed, 111-educated and discontented youngsters and almost ten million under 25 who are in need of help from mental health workers. Some means must be devised to delegate clear respons1bility and authority to insure the well-belng of our young."
\end{abstract}

- Joint Commission on Mental Heaith of Children

This statement, appearing at the end of 1969 , forms part of the introduction to what many feel to be a landmark publication in the fleld of Child Mental Health: Crisis In Child Mental Health: Challenge for the $1970^{\prime} \mathrm{s}$. While this document examines virtually every area which touches upon the well-belng of the child, its recommendations particularly emphasized the creation of a child advocacy system and the development of community health systems which would ensure the full range of preventive and remedial health services to children. Despite the length of the report, actual recommendations for specific. mental health services and clinical services comprised a rather short section.

Oregon's response to the Jolnt Commission Report was contained in Recommendations of the Professional Study Group on the Report of the Jolnt Commission prepared by the Governor's Commission on Youth and appearing in Apri1, 1970. The ten members who drew up this report formed a multi-disciplinary tedm, but none of its members had been a part of the Pllot Project for Emotlonally Disturbed Children which was 
In operation at this time. As a study report, it represented no advance over any of the previous studies, nor did it represent ariy real effort to make any new recommendations. It was important polltically, inasmuch as it was a committee derived from the Governor's Offlce rather than from the Mental Health DIvision, which made it more of an official "Oregon Stand" vis a vis chlldren's programs in the State, while the study group did make some suggestions about programs and manpower training needs which related to some of the findings of the Greenlelgh Report and to the recommendations of the Joint Commission for a Child Advocacy System and community system of health services, they were not tied to any specific objectives, Their strongest message was to urge that no further tine and reoources be taken up with studies. They further recommended that the 1971 Legislature take action on many of the proposals of the Jolnt Commission.

It is an interesting piece of the history of children's programs that the massive Joint Commission Report had as little effect as it did in stimulating developments in children's mental health programs - either nationally or locally. Part of this relates to historical accidents. The stimulus for the Joint Commission came during the Johnson Administration, time of progressive domestic policies, but finally appeared during the Nixon Administration. Thus, while it stands as a definltive statement of the problem and as an articulate formulation of what should be the moral and ethical commltment of this nation to its children, It never gained the support of actual legislative programs which might have made it a practical as well as theoretical contribution to the field of chlld mental health. Two years later, In its critical assessment of the Joint Comnlssion Report, \& 
special ad hoc committee formed by the Group for the Advancement of Psychiatry faulted the commistion for lts fallure to deal with polltical realities, for Its tendency to make sweepling utoplan recoms mendations while eschewing the nitty gritty difficulties of actual clinical programs. 44 At the same time, however, the Group for the Advancement of Psychiatry Committee observed that it was a difficult time to make a critique, inasmuch as Federal and State Programs vere belng retrenched everywhere and children's serylces' were threatened across the nation.

Following the publication of the aforementioned "Oregon response" to the Jolnt Commission Report, mental health programs for children in this state pursued their own course of development, following the Iines laid down by local history, rather than the ideologl cal statements coming from the Joint Coumission. Nonetheless, the years of 1970 and 1971 were important ones for ch11dren's programs in the state and the appearance of the Jolnt Conmission Report probably gave added welght to the proposal for a mental health program for whildren which the Mental Health Division presented to the 1971 legislative assembly. The backbone of this program appeared in an earlier report put out by the sub-committee on Services to Emotionally Disturbed Children, which appeared in July, 1970 and was called simply, "Proposal for a Children's Program." The program proposed represented an amalgam of several agencies approaching the problem and was intended to give the Governor a choice of which agencles he would regard as best suited to carry it

44 "Crisis in Child Mental Health: A Critical Assessment," Group" for the Advancement of Psychiatry, Report No. 82, (February 1972 P. 110. 
out. The program proposed included the following el ements:

1) The Mental Health Division should be the co-ordinating body responslble for:

a. establishting a system of integrated treatment resources.

b. establishing and malntaing a central "knowledge tbank" of resources

2). Specific program recommendations were for (1argely those advocated by the pilot program of 1969):

a. secure treatment untt for children and adolescents

b. small group residential treatment homes in each geographic area

c. Iong term group homes

d. special schools

3) The major new recommendation of the division was for a specialized team that would perform functions that could be called comprehensive integrative, consulting duties (Liaison services, facilitation of referral, provision of knowledge bank, outpatient diagnosis).

It is interesting to note that this idea of a specialized team represented a distillation of the philosophy of the Pllot Program for Emotionally Disturbed Chil dren of 1969 which Included all of these functions in a comprehensive network of services, but which did not cut this program of from other treatment services but emphasized, rather, the finportance of koeping them unifled uncer one administrative umbre11a.

Following some of the foregoing studies and the findings presented by the Pilot Program, the 1971 Legislative Assembly, with the endorsement of Governor McCall, passed H.B. 1869 whlch stated as public policy that the State of Oregon would provide comprehensive mental health services for the prevention and treatment of severe emotional disturbance, psychosis and drug dependency throughout the state. At the same time, leglslation was enacted which oreated the Department of Human Resources and a Children's Services Division as well as the 
Mental Heaith Division within it. At this time, Chlldren's Services Division was made responsible for the administering of the mental health programs for chlldren because it was felt that they were in the best administrative position to contribute all services for the vellbeing of children. Based on the recommendation of the Mental Health Division in 1971 for a Children's Services Section within the Mental Health Division, a Child Study and Treatment Section had been created. With the change in responsibility for children's mental health programs from the Mental Heal th Division to the Children's Services Division, it was decided that the Child Study and Treatment Section would become the mental health planning body of Children's Services. Division and was accordingly transferred to that division.

The functions of the Child Study and Treatment Section are important both historically and programmatically to the developmient of a comprehensive mental health program for children in the state. In its recommendation for a Chlidren's Services Section in the Mental Health Division, Kenneth Gaver had described one of the primary goals of the Children's Services Section as the establishment of "relationships and co-ordination with existing resources, including pediatricians; other private practitioners; private, non-profit organizations; and public agencies Involved in working with children. 45 it is no accident that these goals should be so simllar to those of the 1969 pilot program, Upon the termination of that program, much of the staff from the program were hired to staff the Children's Services Section. Thus, some of the program continuity was maintained; and the planning that would

45"Mental Health Program for Children," Children's Services Sectlon, Oregon Mental Health Divis on 1971-73 Budget Request, (Dec. 1, 1970), P. 9. 
go on in the children's Services Division could draw upon a solid experience with Mental Health Division programs. It is to be expected that the philosophy of the new section (called child Study and Treatment Section after its transfer to Children's Services Division) would incorporate the ideas of a community based system developed through the Pilot Program. In March of 1971, the Portland City Club had pub11 shed a report titled Needed Services for Emotionally Disturbed Children in Oregon. Besides the specific deficits in services which were pointed out in the study, the committee attempted to go beyond the usual explanations offered for the failure at both state and local 1 evels of programs to respond to the children's needs so well docu- . mented in other studies. In its discussion of this failure, the report observed that what was needed was a facility or body to serve as the 'door' - not necessarily performing diagnosttc or treatment functions butserving as a place to glve appropriate referrals." 46 This. is precisely the role which Child study and Treatment Section defined for Itbelf.

In discussing the development of treatment programs, the child

Study and Treatment Section al so reveal ed its own philosophy:

1) The focus is to be on the development of a community treatment system, not just an 1 solated treatment program in a community. The essence of the program is to bring together all the community resources for the mentally and emotionally disturbed child in a comordinated and interrelated approach.

2). Services will be provided enabling the community to become problem solving rather than dependent upon sending the child away to a center or program.

3) Each program must be regarded as unique because of the

${ }^{46}$ Report on Services for Severely Disturbed Children in Oregon, (Portland, Oregon), Portland City Club Foundation, Inc., Vol. 51, No. 42, March 19, 1971, P. 292. 
location; community resources and concorns. As much as posalble treatment goals and methods are established by a team-within the program and its comunity. 47

The role which Child Study and Treatment Section has continued to play in the state's struggle toward a comprehensive plan for children has been a complex one. Taue to its early beginnings in the Pilot Program of 1969 , it has focused its resources on the development of true community systems. Yet, in spite of the fact that this function of a kind of 1 laison, central referral body acting to connect already existing resources was intended only as a model which would then be developed in all the geographic areas of the state, no such development has taken place. At the same time, it has remained the primary co-ordinating body between the Children's Services Division and the Mental Health Division. As much of the altimate responsibility for children's programs has not been clearly defined between the Mental Health Divlsion and the Ch1ldren's Services Division, much of the responsiblity for co-ordination and comprehenslve planning has fallen upon Child Study and Treatment Section, and yet much of its effectiveness in this area has been undermined because of 1 ts uneasy position between the two.

The difficulties of thls position were further increased by large scale re-organization of the Mental Health Division (See A Turning Polint) in 1973. Besides a massive administrative, restructuring, this marked a strong push on the part of the Mental Health Division for the development of Comprehensive Community Mental 47"Report of Activities," CSTS, CSD, Dept. of Human Resources, Unpubli shed Report, (March 1973), P. 6. 
Centers. While the responsibility for children's mental health programs now felf upon the Children's Services Division, the planning by the Child Study and Treatment section for community programs could not help betng affected by this all-out division level support of the Comprehensive Community Mental Hea1th Centers with all of its implications of Fetèral guidelines and counting of Federal money. More concretely, however, the 1973 re-organlzation altered the structure of Child Study and Treatment Section as well. In October 1973 it was placed under Chlldren Services Division's Private Treatment Resources Section. Since then, however, a new plan was developed, according to which the Child Study and Treatment Section Director and three mental health specialists would be transferred from Children Services Division to supervise six of the seven Child Study and Treatment Section Centers 1 isted under the Emotionally Disturbed Children's programs. 48

In splte of the vicissitudes of this kind adininistrative complexity and the frequent lack of clear lines of responsibility, the Child Study and Treatment 'Section wes able to report the following accomplishments in a report of its activities in 1973:

1) The development of community "problem solving" approach built around six new treatment centers in the state. Each of these centers received consultation from a mental health specialist.

2) Development of an information service on chlldren's program.

3) Central referral lialson service provided by the Child study and Treatient Section.

48 "Mental Health Services for. Chlldren \& Youth in Oregon," League of Women Voters, Resource Comittee Material, Pt: II, (Salem, Oregon), Sept., 1974, P. 6.

49 ineport of Activities," CSTS, CSD, Dept. of Human Resources, Unpubl lished Report, (March 1973) 
Many of the complications arising from the confusion of authority and responsiblilty whlch exists between the Chlidren's Services Divialon, the Child Study and Treatment Section and the Mental Health Division are documented in an excellent two part study done by the League of Women Voters in 1974. It also provides an excelient updating of many of the special programs contracted for by the Children's Services Division. For several reasons, however, the focus of this paper will remain upon the activities of the Child Study and Ireatment Section. First of all, because that unit in its phlosophy and programing, retains the strongest 1 ink to historical developments in Oregon. Secondly, because it has taken upon itself a central role in doing the planning for a comprehensive mental health program for chlldren in the state and thus has a singlular hold on the future of children"s programs in the state. Thirdly, because the Child Study and Treatment Section has been largely responsible for defining a community system of care for children In the state. Yet this is quite different from the model of the Comprehensive Communtty Mental Health Center supported by the Mental Health DIvision in 1973. As has been seen, the Comprehensive Community Mental Health Centers in Oregon have never been kind to the advancement of children's programs. Indeed the services provided children in these centers fell from $50 \%$ in 1964 to an alp time 1 ow of $27 \%$ in 1974,50 In an interview wi th Ron Marsha11, Director of the Child Study and Treatment Section, he was quoted as saying that the six treatiment centers in the state represent a program that is "a real pilot for the nation", for a center

\footnotetext{
50 "Mental Health Services for Children \& Youth in Oregon," League of Women Voters, Resource Committee Material, Pt. II, (Sal em,
} 
that is really community-rooted and community responsive and becomes a base for a treatment system. 51 While the philosophy of the Child Study and Treatment Section has always supported a principle of coordinating and mobilizing existing resources which of ten includes "uncovering latent talents" rather than training them, remairing silent rather than advising, and waiting, rather than urging, it is a singularly difficult goal to achieve. While the achievements of the Child Study and Treatment Section should not be underrated, a critical examination of some of the recent developments is essential to predicting and assessing future developments. It is noteworthy, for example, that the Child Study and Treatment Section's original plan for the $\$ 1 x$ treatment centers throughout the state called for. them to be state administered. Because of a budgetary crisis, at that time, however, it was necessary for the Child Study and Treatment Section to change its deslgn and go through the much longer process of consulting with the six centers to help them become private, nonprofit corporations (which necessitated completely local planning) in order to be eligible for Federal support. Thus, while the final result of genuine comminity involvement certainly supported the Child Study and Treatment Section's philosophy of the community-based systems, the results might have been very different if the programs had been established, administered and operated by the state, as originaily planned.

This, then raises some difficult questions. Is it possible for a state planning body to "plan" a local communlty program? or even to

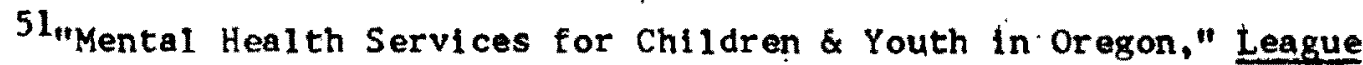
of Women Voters, Resource Conmittee Materiai, Pt. I, (Sal em, Oregon), Sept. 1974, P. 13. 
help the local people plan thelr own program? How is it possible for a body whose administrative responsibility derives from a state level division to "co-ordinate and mobilize agencies and professionals (or non-professionals) whose impact on the problems of emotionaliy disturbed children is great, but whose source of authority may be very different, Indeed in conflict with that of the state's. On the other hand, if a body such as the Chlld Study and Treatment Section puts on its "community hat" and sollcits the idiom of entirely local needs, how is it possible to Bssemble a truly comprehensive plan? It may well be that no answers to these questions are ever possible, but it is important to keep them in mind in understanding the struggle that has been inevitable between 1 ocal and state forces as planners have worked toward a comprehensive plan. 
CHAPTER $v$

NORTHWEST REGIONAL FORUMS

A concrete step was taken toward this goal in September, 1975

when a grant from the National Instil tute of. Mental Health helped to bring about the Northwest Regional Forum on Mental Health Services for Children, sponsored by the Oregon Mental Health Division, Mental Health Assoclation of Oregon and Citizens for Children. According to a memorandum sent out by Fred Letz; "The coming together of diverse Interests to work toward the common goal of effective service to children was a major thrust of our first forum and will be a continuing thene throughout the remaining meetings." The intent, of this four-state meeting was to share information, mobilize interest, generate ideas and in general to set the stage for the hard core work of state planning which was to follow. The plan to gather concrete information from around the state in local regional meetings is al so contained in the memorandum from Assistant'Administrator Fred Letz:

"A planning comml ttee, chaired by Vern Faatz, developed the first statewide forum and has outlined the purposes and broad format of the reglonal forums. The goal of regional forums is to assist counties to gather information on mental health needs of children for county plans and a six year state plan for children. Regional forums are invisloned as belng local1y planned by staff from community mental health programs, Children's Services Division, and other local persons and agencles. The communlty mental health programs, working alone or together, would conduct county or reglonal forums to build on the success of the First Northwest Regional Forum.

"Discussions have been held with reglonal specialists asking them to facilitate the planning of regional forums. The state of fice of Children's Services DIvision has been involved in this planning process and has requested its reglonal of 1 ces to cooperate in planning county or regional... Members of Vern Faazt's planning comtittee are ready to assist county or regional groups in planning and implementing regional forums.

"It is hoped that out of the regional forums will come goals, 
directions, and strategles that will carry us into the coming legislative year with a coordlnated effective, and concentratued volce advocating sound treatment services for chlldren, youth and their families. 52

The intention of the combined statewide and local forums was, then, to work toward that difficult goal of integrating comprehensive. state planning with 1 ts attendant guidelines and standardized program definitions, with the idiom of expressed local need already discussed. In the previous chapter.

The Child Study and Treatment Section staff within the Mental Health Division who were already Involved in the state plan for children were largely responsible for initiating the guidelines for the forums and integrating the results.

The questions which I was interested in, then, as I looked at these forums was: how did each area plan and bring about the local forums? How did they solicit Information? Were the forums generally successful in: 1) complling local oplnions and needs 2) contributing substantively to the comprehensive state plan for children?

My original plan for studying the way the forums were conducted and for gaining an 1 dea of their general impact and effectiveness was to attend as many of the local forums as possible as an observer/ recorder and where impossible, to interview those in charge of planning and conducting the forums I was unable to attend. In order to be useful to the Mental Health Division In its budget planning for 1977-78, the information from the county or reglonal forums had to be returned to the program office by Apr 11 1, 1976. As this corresponded

52 Memorandum from Fred Letz to the three Regional Directors, dated January 2, 1976 : 
approximately to the time period which I had avallable to me prior to my own deadilne, this seemed like a practical approach. As it turned out, several things happened which led to a change in the way I approached the problem. First of all, the first regional forum, which was held jointly for seven southern counties, occurred shortly after I had decided to follow the forums, and I was notlfied too late to attwnd it. Most importantly, however, was the fact that several months went by, and as the deadline approached, none of the anticlpated forums had materialized. To my other questions was now added curlousity about several other areas. Why had they not been held? What obstacles had been encountered? If they still intended to hold them, would their purpose - and effect - be altered by the fact that their results could not be made avallable to the planning office until after the deadline for the Division Budget planners.

$I$, therefore, determined to write directly to the people in charge of planning the forums to ask them some questions about how they went about planning them, what obstacles they encountered and how they felt about the results. A copy of the letter and the questlonnalre can be found in Appendix $C$ and $D$. The other part of my approach consisted of talking to the people in the state offlce of the Child study and Treatment Section to determine how they set up guidelines for the forums and how they contributed to the planning. According to the original design the mental health specialists from the state office were to be available for consultation but the local directors were to be responsible for inttlating and carrying them out. From them, I was able to obtain coples of the forms which the state office sent to the program directors of each of the geographic areas. Copies of these 
forms can be found in Appendix E - G. An examination of these forms

led me to several tentative conclusions:

1) A certain uniformbty of information was belng sought by the planning committee.

2) Although each area was mandated to do its own planning for the forum, the state planning committee was in fact encouraging if not forcing them to conceptualize solutions in terms of formal programs already defined by the Mental Health Division.

3) While theoretically, many people outside of the formal mental health system were to be invited to participate in the forums, it appeared that the elaborate and rather technical nature of the format used for gathering information might discourage people without experience in program planning or with a limited knowledge of existing resources.

It seemed well designed to collect information that fit into the usual kind of planning, process which is marked at the state level by such things as "categories of service," fiscal support and prioritization," but might be insensitive to the information whlch would be contained in the answers to the following questions:

1) How does your community react to emotional1y disturbed children?

2). How are such children currently served outside the existing programs?

3) What are the satisfactions and dissatisfactions with existing programs?

4) What is inost needed to help the caregivers do a better fob in provising servides, to these children?

As comparloon It is worthwhile to note a contrasting method employed by a study undertaken in the school systen of Onandaga, New York. In that study, particular attention was paid to the manner in which informatton was elliclted. As described in the study, "The Interview gulde was designed to give each teacher an opportunlty to 
describe problem behnvior in his ot her own way." 53

After gaining these preliminary impressions of the process involved in organizing the forums, the results of the questionnalres were of particular interest. The response rate was not encouraging primarily because very few of the forums were utilimately held. The returns are sumnarized below:

\begin{tabular}{|c|c|c|c|c|}
\hline $\begin{array}{l}\text { County or } \\
\text { Region }\end{array}$ & Reglonal Forum & leld & & $\begin{array}{l}\text { Questi onnal re } \\
\text { Returned }\end{array}$ \\
\hline Mul tnomati & $\begin{array}{l}\text { Steering Committee si } \\
\text { ing to plan forum }\end{array}$ & still meet- & & Yes \\
\hline Clackamas & $\begin{array}{l}\text { Conducted by mailed } \\
\text { naires after forum } \\
\text { jected by steering } \\
\text { mittee }\end{array}$ & $\begin{array}{l}\text { question- } \\
\text { was rem } \\
\text { com- }\end{array}$ & . & Yes \\
\hline Col umbia & No & & & No \\
\hline Washington & No & . & & No \\
\hline $\begin{array}{l}\text { Clatsop } \\
\text { Tillamook } \\
\text { Lincoln }\end{array}$ & Planned by Clatsop & County & & Yes \\
\hline $\begin{array}{l}\text { Marion } \\
\text { Potk } \\
\text { Yamhill }\end{array}$ & $\begin{array}{l}\text { "pre-meetings" were } \\
\text { Forum was rejected } \\
\text { held. }\end{array}$ & $\begin{array}{l}\text { held. } \\
\text { never }\end{array}$ & & Yes \\
\hline $\begin{array}{l}\text { Crook } \\
\text { Deschutes } \\
\text { Jefferson }\end{array}$ & No & & . & $\begin{array}{l}\text { Yes - wl th note } \\
\text { saying no time } \\
\text { to fill te out. }\end{array}$ \\
\hline $\begin{array}{l}\text { Linn } \\
\text { Benton }\end{array}$ & $\begin{array}{l}\text { No } \\
\text { No }\end{array}$ & $\because$ & & $\begin{array}{l}\text { Yes } \\
\text { No }\end{array}$ \\
\hline Lane & No & & & No \\
\hline $\begin{array}{l}7 \text { southern } \\
\text { counties }\end{array}$ & Yes. & . & & $\begin{array}{l}\text { No, but results } \\
\text { of forum were } \\
\text { forwarded to me. }\end{array}$ \\
\hline Region III & No & & & No \\
\hline
\end{tabular}

While the return rate was not high enough to make definite conclusions possible, there were many trends that were clearly indlcated by those recelved. Those counties which recorded what they regarded as

53Elemientary School Chlldren with Persistent Emotional Disturbances. A Summary Report of a Study in Onandaga County, N.Y. (AIbany, N.Y.: New York State Dept. of Mental Hygiene; Dec. 1974), P. F. 
a high percentage of useful information were uniformly those which changed the original plan of the forums so that they were conducted by " "select group;" that is, el ther a steering commlttee or representatives who were contacted from certain key agencies. On1y one of the respondents felt that there were no serlous gaps in the repnesentation of the forum; the others mentioned the attendance primarily of key professional mental helath agencies, such as Children Services Division, Mental Health Division and clinic directors. Most of the respondents gave answers to ef ther No. 2 , No. 3 or No. 5 that indicated that they felt dominated or "managed" by the Mental Health Division or state planners. To give a feel for this reaction, some of the responses are quoted in full below:

\footnotetext{
"The forum representatives themselves sort of laid on the people thelr package of ideas."
}

There, was some resistance (by the steering commlttee), toward. having it headed by the Mental Health Division.

"Meetings were dominated by the Mental Health Division staff, mental health programs and Children Services Division staff from three counties."

"No point gathering a lot of people at this time when we 'know' the Mental Health Division budget is already locked in."

In response to question No. 4, all of the respondents replied that they did not use the recommended format and did not find it useful. The responses to questions No, 6 and No. 7 indicated a clear diviston between those counties which had wide representation and those which were done through a steering group or representative body. The former recorded - without exception. - negative responses. Below are samples of their responses:

: "Perhaps (the local forums would be effective) if more time 
(were) spent in listening to what is happening at a local level rather than laying on certain models for us to react to or deçide on."

(Do you have any suggestions for improvement...?)

"Yes, make the planning and purpose of forums more realistic and responsive to rapidly changing reallty plcture at the local level."

\footnotetext{
"Those prasent refused to plan: 'we've been needs surveyed to death."'

It is interesting that the most optimistic reply came from a
} county which was still in the planning stages and was handling the preparations by a serles of regular meetings in advance of the forum. What is striking, however, is that whlle they saw little value in the forum as an information gathering process ("We all know what the serlous service gaps are,") the notes of their meetings indicate a growing investment in the process itself, so that in the final meeting, much of thelr goal setting revolves around such things as developing permanent Interagency meetings, "getting people to talk to each other." Perhaps, such is the natural outgrowht of people gnowing in trust and familiarity with each other.

What, then, are some of the implications of these results - as $11 \mathrm{mited}$ as they might be? First of all there seems to have been considerable difficulty in bringing them about. As a result of the number that elther did not take place, or else occurred after the Apri1 I deadline, "local input" into the State Plan was necessarlly yery $1 \mathrm{imlted}$. If the responses received were any indication, the dominant mood seemed to be one of impatience and discouragement with the imbalance between frequency of surveys and studies and that of actual changes. A reaurrent theme, on the other hand, seemed to be that a "one-shot", forum such as this probably cannot provide the sensitive 
feedback mechanism between state and local service givers which would give information about service needs and priorities to the former. This does not mean that such forums have no utility but in order to make them useful, it might be necessary to look more carefully at the process which goes on between people when they get together around such a probiem, and redefine a model which would maximize rather than frustrate this interaction. This is certainly not a simple process. In an earlier study on the treatment planning process in the community, a Group for the Advancement of Psychiatry Committee observed: "As child mental health workers become more involved with other professionals and concerned laymen in the community, the opportunities for creative planning becomes more complex and difficult." 54 In ang case, the skepticism about combining state level planning with local "needs assessment" which concluded in Chapter IV appears to have been somewhat justified. The dilemma of how to involve those who are not paid to concern themselves with the emotional problems of children is an ongoing one. It was the same probiem expressed in 1971 by the Portland City Club:

"The voices crying for more facilities, services and expenditures for emotionally disturbed children have thus far been primarily those of the professionals in the fleld.... There are other citizens, however, who are aware of the crisis. These include volunteer workers in Juvenile detention facilities and mental health services, school personnel, et al... (whose) volces in support of proposed programs and funds for emotionally disturbed chlldren are badly needed. 35

54"From Diagnosis to Treatment: An Approach to Treatinent Planning for the Emotionally Disturbed Child," Group for the Advancement of Psychlatry, Vo1. VIII, Report No. 87, (Sept. 1973), P. 568.

55 Report on Services for Severely Disturved Children in Oregon, (Portiand, Oregon), Portland City Club Foundation, Inc., Vol. 51, No. 42, March 19, 1971, P. 291. 


\section{CHAPTER VI}

PEDIATRICIANS AND THE CHILD MENTAL HEALTH SYSTEM

IN OREGON

Having spent the previous chapter in consideration of one generai process involved in the goal of making state planning truly responsive to $10 c a 1$ riedd and in helping communitles mobilize thelr own local resources, it is time to examine more closely how one such local resource, pediatriclans in the state, fits into the system of caregiving which is only partlally comprehended when one understands the formal mental health system.

There is much in the general literature to suggest that pediatriclans have widespread involvement with emotionally disturbed children. There is also much to suggest that there may be considerable barriers to mutual collaboration between pedlatriclans and mental health professionals who deal with the needs of children. In a speclal study on the relationship between pedlatrics and child psychiatry, a Group for the Advancement of Psychiatry commlttee made the following comment on some of the professional obstacles to the development of children's programs:

"There is the interface...between differing models of development. The pediatrician defines development one way, the neurologist somewhat differently. Neither one sounds much like the psycholanalyst... who in turn finds his views at variance with those of the child-development specialist. While these approaches are not mutually exclusive, the nature of facilities and staffing patterns evolving from the concretization of the dealls of service for ghildren, is profoundly affected by variation in schemata employed. 56

56"Crisis In Child Mental Health: A Critical Assessment," Group for the Advancement of Psychiatry, Report No. 82, (February 1972), P. 116. 
Notwithstanding these difficulties, however, the importance of the pediatrician in this process seems to be well established. Even in 1951 , a study in this state reveal ed that approximately $60 \%$ of a pediatrlcian's practice concerned problems of mental heal th and development. 57 In a comprehensive study which provided the basis for the comprehensive state plan for chlldren in Rhode Isiand, study members concluded that "pediatricians are the first professionals parents are likely to turn to when seeking help for thelr chlld and themselves." 58 In Maine, where similar work was being done to make a comprehensive plan, it was found that physiclans as a group made up the third highest referral source to the Comprehensive Communlty Mental Health Centers. 59 In Oregon, physicians made up $7.9 \%$ of the total referrals to Comprehensive Community Mental Health Centers for the year 1973-74, but in some counties, the percentage was as htgh as $38 \%$. 60 In looking at these statistics, it would also be well to remember that in oregon, the Comprehensive Community Mental Health Centers have represented a dwindling resource for children, and therefore these figures probably underrepresent the numbers of these children being seen by pediatricians who are not referred to the Comprehensive Community Mental Health Centers.

57 Mental Health Services tor. Children and Youth in Oregon (Portland, Oregon: Oregon Governor's State Comittee on Children and Youth; 1950), P. 33 .

$58 \mathrm{Joseph} \mathrm{J}$. Bevilacqua, "Position Statement on the Planning of . Mental Health Services for the Children \& Youth of Rhode I sland," Dept. of M.H., Retard, \& Hosps., DIV. of Y.H., (Jan. 19.75, unpublished report), P. 196

${ }^{59}$ State of Malne, Comprehensive Plain for Mental Health Services to Children, Dept. of Mental Health \& Corrections, (July 1974), P. 85.

60 Coppllation of Dats on Children: Annual Report; Comm. Men. Health Programs (0.M.H.D., Sal em, Oregon, 1973-74), P.5. 
It has been pointed out with mounting frequency that in pediatrlc practice concern with curing infectlous disease has been supplanted by greater attention with health promotional activities, which has led to concern with mental health. 61 organized pediatrics has increasingly recognlzed its strategic position in the prevention and treatment of children's behavior and personality disorders. 62 The Importance of the pediatriclan to the process of early diagnosis and detection of emotional disorders, particularly in the case of young chiluren, can hardly be overestimated. In the Pllot Study of 1969 , staff at the Child Diagnostic Center found that all of the referrals for very young chlldren come from medical sources whlch led them to make the strong, recommendation that pediatricians recelve concentrated training in recognizing signs of emotional problems. 63

Understariding and helping to improve the abilities of pediatrlclan to recognize and diagnose emotional problems in children is certainly a key part of any primary prevention program, but it is only one part of the way that pediatricians are integrated into the total children's mental health system. In an article on alternatives to residential care for mentally and emotionally disturbed children, done in Mlchigan, success of the program was pinned to the high level of involvement of non-mental health workers with the planning for and

61"The Contribution of Child Psychiatry to Pediatric Training and Practlce," GAP, Report 21 (Jan, 1952), P. 1.

${ }^{62}$ Hale F. Shirley, Psychlatry for the Pediatrician (New York: Oxford Univ. Press, 1948), p vil.

${ }^{63}$ Pilot Program for Emotionally Disturbed Children (Salem, Oregon: 0.M.H.D., Unpublished Report, Feb. 1969), P. 9. 
actual treatment of the children. In the 25 cases, 27 comunity agencles were involved, but the only agency active in a11 25 cases was the physician. ${ }^{64}$ It is also important to determine the nature of the referral system which pediatricians use. Are they comfortable maklng referrals to mental health professlonals and working collaboratively with them? Are they satisfied with them? Finally, it should be determined to what extent pediatricians give or attempt to give primary care to children whom they perceive as emotionally disturbed. While the Taylor Report of 1964 surveyed pediatricians in an attempt to determina the number of contacts they had with emotionaliy disturbed chlidren, no study has attempted to answer any of the questions just posed. It was with the hopes of providing some of this information that I constructed the questionnalre which I sent out in January, 1976. Methodology

In the State of Oregon there are currently close to 20011 censed pediatriclans. The distribution of them in the state is shown in Appendix I. As physiclans tend to be a difficult group from which to obtain a high response rate, I selected the entire population as my study group. Out of 198 11 censed pediatricians, I was able to obtain addresees for 180. Before sending the questionnalre to them, however, I pre-tested it with four pediatricians in Portland. As a result of some of their comments and some rethinking of my own, I modified the format sightly. The orlginal questionnalre appears in Appendix $J$,

${ }^{64}$ Archie McKinnon, et al, "The Child Guldance Clinlc: Catalyșt \& Co-ordinator in Community Treatment of the Psychotic Child.", Communl ty Mental Health Journal, Vol. 4 (4) (1968), R. 308. 
while the final revised one appears in Appendix $\mathrm{K}$. I sent the questionnalre then in January, 1976. As I was operating on a very 1 imited budget, I was unable to send follow-up letters to improve my response rate.

\section{Data Presentation}

Out of the 180 questionnalres sent, 21 were returned with some. kind of explanation which disqualified them from the total sample (1.e., respondent deceased, retired, moved out-of-state, etc.) leaving a final study population of 159. Out of this population, then, I recelved 47 usable returns, glving a total response rate of $30 \%$. In presenting the data, I have grouped it under the following headings:

I. Characteristics of Study. Population

II. Magnitude of Problem

III. Provision of Treatment and Use of Consultation

IV. Vtllization of Referral Resources

V. Satisfaction with Referral Resources

VI. Summary

As some of the information retrieved was only for my own information or to make certain the response was a valld one to Include, I have not shown the responses to all of the questions.

\section{CHARACTERISTICS OF STUDY POPULATION}

The counties listed as served by the respondents included all but the following 17:

Columbia

Tillamook

Hood River

Wasco

Jefferson

\section{Wall owa}

Union

Morrow

Grant

Wheeler 
Lake

Harney

Mal heur

Baker

According to Appendix $I$, however, only one of those counties

which were not 1 isted as served by any of the responding pediatricians shows a licensed pediatrician serving it. Twenty-five of the 47 respondents. 1 isted Multnomah County for the county served. Wh1le this appears to be a high proportion of the total responses, it is actually only $23 \%$ of the pedlatricians practicing in Multnomah County, much lower than the general response rate. Other demographic data is given below:

Practice primarily:

Metropolitan $\quad 32$

Rural $\cdot 7$

Both 6

No Response

Tota1 47

Years in practice as a pediatrician:

$\begin{array}{lcll}\text { Range: } & 1-38 & \text { Median: } & 14 \\ \text { Mean: } & 14-7 & \text { Mode: } & 10,25\end{array}$

Age:

$\begin{array}{lcll}\text { Range: } & 32-68 & \text { Medlan: } & 44 \\ \text { Mean: } & 54.2 & \text { Mode: } & 34,36\end{array}$


Sex:

Male: $\quad 40$
\begin{tabular}{l}
5 \\
Female: $\quad 5$ \\
No Response: $\quad 2$ \\
\hline
\end{tabular}

Total $\cdot 47$

In general, the respondents are representative of the total population, though a look at Appendix I suggests that the urban ar s recelve somewhat higher representation, and respondents are somewhat older than the statistcal average.

\section{MAGNITUDE OF PROBLEM}

In answer to question No, 1, (See Appendix K), respondents report - that the following percentage of thelr pediatric practice is made up of children with mental or emotional disturbance:

TABLE I

PERCENTAGES OF MENTALLY-EMOTIONALLY DISTURBED CHILDREN SEEN BY PFDIATRICIANS (1)

\begin{tabular}{|c|c|c|c|c|c|c|c|c|c|}
\hline & $0-10 \%$ & $10-20 \%$ & $20-30 \%$ & $40-50 \%$ & $50-60 \%$ & $60-70 \%$ & $70-80 \%$ & $80-90 \%$ & N.R. \\
\hline <5 Yrs. & 28 & 11 & 3 & 1 & 2 & 0 & 0 & 1 & 1 \\
\hline $5-9$ Yrs. & 20 & 13 & 7 & 2 & 1 & 1 & 0 & 1 & 2 \\
\hline $10-14$ Yrs. & 20 & 13 & 5 & 2 & 3 & 0 & 1 & 1 & 2 \\
\hline Total & 68 & 37 & 15 & 5 & 6 & 1 & 1 & 3 & 5 \\
\hline
\end{tabular}

(N.R. - No Response)

If the first two categorles and then the first three categories are collapsed into two categories, the following percentages of the total results would obtain:

TABLE II

\begin{tabular}{|c|c|c|}
\hline$<5$ years & $0-20 \%$ & $0-30 \%$ \\
\cline { 2 - 3 } $5-9$ years & $85 \%$ & $91 \%$ \\
\hline $10-14$ years & $73 \%$ & $88 \%$ \\
\hline
\end{tabular}


While these responses are only general Indicators, they suggest that most of the estimates of emotional disturbance correspond roughly to the figures of $8-15 \%$ which have appeared in other studes. It can also be seen that generally speaking in the pediatricians' eyes, the older the child, the more problems he has. In other words, in their view, a lower percentage of mental and emotional problems are seen in the very young child $(<5$ years) while the two older groups present profiles remarkably similar to each other, the latter showing only a somewhat higher percentage of disturbance.

In answer to No, 2 (See Appendix K), the following raw numbers of children with mental and emotional disturbance were sald to have been seen in the past six months:

$\begin{array}{ll}\text { Total: } & 4,778 \\ \text { Range: } & 1-1,000 \\ \text { Mean: } & 119.45 \\ \text { Medlan: } & 75 \\ \text { Mode: } & 50\end{array}$

Stated in another way, pediatrlcians who responded, saw an average of one emotionally-disturbed child per day. If one projects the percentages of 8 - $15 \%$ over the average pediatrician's patient load, this would seem to represent elther signiflcant underreporting or emotional disturbance that is going unrecognized.

In analysing the responses to No. 3, I added the category of 1 age grop as many of the respondents replied that more than one age category is most in need of services. Responses are as follows: 


$\begin{array}{cr}<5 \text { years } & 4 \\ 5-9 \text { years } & 9 \\ 10-14 \text { years } & 17 \\ 1 \text { age group } & 10 \\ \text { No response } & 7 \\ \text { Totei } & 47\end{array}$

It is striking that of those pediatricians who list only one age category, $57 \%$ see the age group of $10-14$ most in need of services. This is particularly interesting in view of the fact that many pedltriclans do not see adolescents. These results may suggest that they see themselves as treatment resources for the two younger age groups. It is also interesting in that the emotionally disturbed adolescent tends to have high contact rate with the fudlcial system and school system' than the younger chl1d.

III. PROVISION OF TREATMENT AND USE OF CONSULTATION A11 of the questions in this section were designed to make up a composite pleture of how an emotionally disturbed child gets treatment after the initial contact with the pediatrician is made. The results for question No. 4, in which pediatriclans were asked to describe the percentage of children for whom they provided primary treatment and those whom they referred elsewhere, are broken down in two diff erent ways, as follows: 
TABLF III

PERCENTAGES OF CHILDREN

TREATED VS THOSE REFERRED

\begin{tabular}{|c|c|c|c|c|c|c|c|c|c|c|c|}
\hline & $\begin{array}{c}0.10 \\
\%\end{array}$ & $\begin{array}{c}10-20 \\
\%\end{array}$ & $\begin{array}{c}20-30 \\
\%\end{array}$ & $\begin{array}{c}30.40 \\
\%\end{array}$ & $\begin{array}{c}40-50 \\
\%\end{array}$ & $\begin{array}{c}50-60 \\
\%\end{array}$ & $\begin{array}{c}60.70 \\
\%\end{array}$ & $\begin{array}{c}70-80 \\
\%\end{array}$ & $\begin{array}{c}80-90 \\
\%\end{array}$ & $\begin{array}{c}90-100 \\
\%\end{array}$ & \\
\hline $\begin{array}{l}\text { Provide } \\
\text { primary } \\
\text { treatment }\end{array}$ & .7 & 2 & 2 & 2 & 0 & 9 & 2 & 2 & 7 & 14 & 1 \\
\hline $\begin{array}{l}\text { Refer to } \\
\text { a nother } \\
\text { trea tment } \\
\text { source }\end{array}$ & 9 & 11 & 7 & 2 & 1 & 8 & 0 & 2 & 0 & 5 & 2 \\
\hline $\begin{array}{l}\text { Nel ther } \\
\text { treat nor } \\
\text { refer }\end{array}$ & 34 & 3 & 4 & 1 & 1 & 1 & 0 & 1 & 0 & 0 & 2 \\
\hline
\end{tabular}

(N.R. - No response) :

TABLE IV

TRFATMENT VS RFFERRAL: MEASURES

OF CENTRAL TENDENCY

\begin{tabular}{|c|c|c|c|}
\hline & Mean & Median & Mode \\
\hline $\begin{array}{c}\text { Provide primary } \\
\text { treatment }\end{array}$ & $57.5 \%$ & $60 \%$ & $50 \%$ \\
\hline $\begin{array}{c}\text { Refer to another } \\
\text { treatment source }\end{array}$ & $31.6 \%$ & $20 \%$ & $10 \%$ \\
\hline $\begin{array}{c}\text { Nel ther treat } \\
\text { nor refer }\end{array}$ & $7.4 \%$ & 0 & 0 \\
\hline
\end{tabular}

Several patterns are observable. First of all, the percentage

of chlldren who were placed in the category of neither treated nor

referred is very 1 ow, with an average of $7.4 \%$ reported in this group, but even more significantly, with 32 respondents reporting that of the children they saw there were none who fell into this categoryl Put in the jargon of current mental health terminology, there were very few chlldren who did not at least go through the process of being "hooked up" with a treatment source. Secondly, the percentage of referrals made is surprisingly low, with a mean of only $31.58 \%$ and with a median. $(20 \%)$ and mode $(10 \%)$ that suggest an even lower overal1 pattern. Correspondingly, the percentage of children whom pediatricians report they 
are providing primary treatment is much higher than expected, with a mean of $57.5 \%$, a median of $60 \%$ and a mode of $50 \%$. From these results, It would be interesting to determine if pediatriclans are providing most of the treatment themselves because they feel most competent to do it, or if it is because they are elther unaware of or dissatisfied with avallable treatment resources.

In interpreting these results, however, it is important to recall that in question No. 2, the percentages of emotionally disturbed children making up their practlce was surprisingiy low. The results of the two questinns taken together may suggest that a pediatrician tends to recognize or diagnose those problens which he feels competent to handle. The very small numbers who are reported as recelving neither treatment nor referral could relate to what might be a significant number who are going unrecognized and "undiagnosed." (These vords are probably inadequate to describe the experience of encountering a problem in one's practice which is anxiety provoking and which the practitioner feels he "ought bo be able to handle" but whlch his long years of specialty training did not prepare him for. If his self confldence is high and his professional relationships are good, the result will probably be a quick referral. If not, the ultimate resolution may be that the problem is not viewed as a problem - or at least is not reported as one,)

In question No. 5, respondents were asked both whether or not they utilized consultation if they provided primary treatment and whether or not they felt that there should be more of such consultation services. The results are summarized as follows: 
Utilization of mental health consultation:

Yes:

45

No:

1

No Response

1

Total

47

Should more consultation

\begin{tabular}{lc} 
Yes: & 26 \\
No: & 14 \\
No Response & 7 \\
\hline Tota1 & 47
\end{tabular}

The high rate of utilization of consultation services is noteworthy. Respondents were also asked to 1 ist thelr favorlte sources for conultation services, if they used them. The sources mentioned are 1 isted below, in descending order of frequency:

TABLE $V$

CONSULTATION RESOURCES USED

Prlvate psychologist Private psychiatrist. Mental Health Clinic Medical School C. D.R.C. other Counsel ling Private Agencles (Morrison Center, etc.) 3 Children Services Division Community Services

O.R.I. other

No response

(The percentage indicates the percentage of respondents who mentioned the given resource; as some mentioned more than one, the column totals more than $100 \%$.)

\begin{tabular}{cc} 
No. & $\frac{\%}{45}$ \\
\hline 19 & 31 \\
13 & 31 \\
13 & 12 \\
5 & 9.5 \\
4 & 9.5 \\
4 & 7 \\
3 & 7 \\
3 & 7 \\
3 & 5 \\
2 & 5 \\
2 & 12 \\
5 & \\
ge respondents who \\
ment oned more than \\
)
\end{tabular}


It should be noted that private sources hend the list, but it is surprising that between psychiatrists and psychologists, the latter are mentioned more frequent1y. It could be speculated that the 1 ines which demarcate the area of expertise are clearer between the pediatrlctan and psychologist are clearer than those between a pediatrician and chl 1d psychtatrist. In general, requests for consultation come most easily when one's professional identity is secure. It also suggests that more frequent requests for consul tation from a psychologist may indicate that the pediatrician tends to see many of the mental and emotional disorders as learning disabilities. This tendency seems to be substantibted by the frequency of their contacts with the schools, which is revealed in the next section.

It is particularly interesting, however, to compare the results of this question with the results of the last question, in which respondents were asked to name the profession or resource which they would take thelr own child to if he/she were mentally or emotionally disturbed. The results - again, listed in descending order of frequency appear below:

TABLE VI

PREFERRED RESOURCE FOR PEDIATRICIAN'S FAMILY

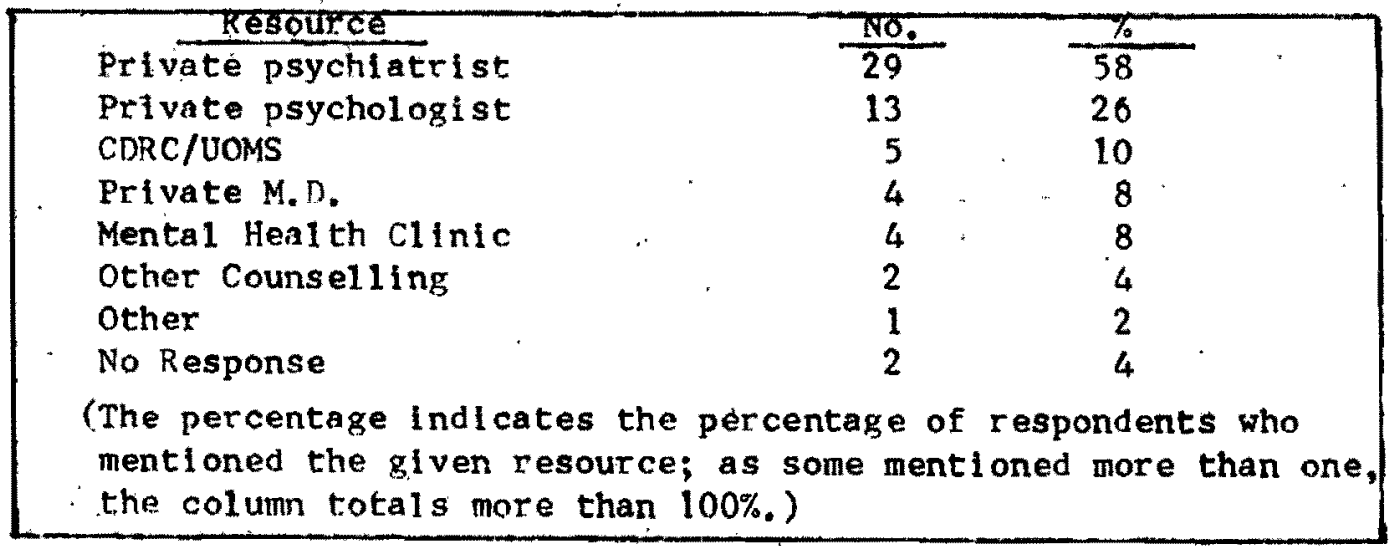


Thls question was intended as a kind of "after all is sald and done, whom do you really see as competent? whom would you trust to care for your own child?"i Query. While it is very difficult to quantify the Implications ralsed by the results, they nonetheless add a very Important dimension whlch is useful in interpreting some overall trends. The response in favor of private psychlatrists is overwhelming. The relationship between psychiatrists and psychologists seen in the previous question is here reversed. Whatever made psychlatrists 1 ess popular as a source of consultation does not seem to apply in the case of seeking help for the respondent's own children. Another contrast is revealed in the different usage of pubilc agencies (including mental health clinics) Indicated by the responses from the two questions. While in question No. 5, a $61.5 \%$ usage of public agencies is show, in question No. 11 , only $20 \%$ is shom (and out of this, $11 \%$ is accounted for by UOMS/CDRC which enjoys a special relationship to the medical community.) A more complete picture of the referral system is seen in the next section.

IV. UTILIZATION OF REFERRAL RESOURCES

In organlzing the results of this section I presented the data first in the categorles which appeared on the questionnalre with the addition of a per cent column and then collapsed the five colums into three to show a low moderate, and high frequency response pattern. These results are shown on the two pages following. 
TABILE VIT

REFERRAI RESOURCES USED BY PEDIATRICIANS (1)

\begin{tabular}{|c|c|c|c|c|c|c|c|c|c|c|}
\hline$\cdot$ & & & $\begin{array}{l}\text { Used } \\
\text { Rare }\end{array}$ & & $\begin{array}{l}\text { Used } \\
\text { Occas: }\end{array}$ & na11y & $\begin{array}{l}\text { Used } \\
\text { Moder } \\
\text { Fregu }\end{array}$ & $\begin{array}{l}\text { ith } \\
\text { te } \\
\text { ncy }\end{array}$ & $\begin{array}{l}\text { Used } \\
\text { Freq }\end{array}$ & $\begin{array}{l}\text { very } \\
\text { ently }\end{array}$ \\
\hline - · & No. & & No. & $\%$ & No. & $\%$ & No. & $\%$ & No. & $\%$ \\
\hline $\begin{array}{l}\text { Children's Services } \\
\text { Division }\end{array}$ & 9 & 20 & 11 & 24 & 15 & 33 & 11 & 24 & 0 & 0 \\
\hline Mental Health C1Inics & 7 & 15 & 6 & 13 & 16 & 35 & 14 & 30 & 3 & 7 \\
\hline $\begin{array}{l}\text { Family Counsel ing } \\
\text { Services }\end{array}$ & 11 & 24 & 13 & 28 & 18 & 39 & 4 & 7 & 0 & 0 \\
\hline $\begin{array}{l}\text { Private } \\
\text { Psychiatrists }\end{array}$ & 6 & 13 & 12 & 26 & 18 & 39 & 9 & 20 & $i$ & 2 \\
\hline $\begin{array}{l}\text { Private } \\
\text { Psychologists }\end{array}$ & 8 & 17 & 10 & 22 & 18 & 39 & 7 & 15 & 3 & 7 \\
\hline $\begin{array}{l}\text { Private Practicing } \\
\text { Soclal Workers } \\
\end{array}$ & 26 & 57 & 13 & 28 & 4 & 9 & 2 & 4 & 2 & 4 \\
\hline Ministers & 21 & 47 & 17 & 37 & 6 & 13 & 2 & 4 & 0 & 0 \\
\hline Juvenile Courts & 21 & 47 & 16 & 35 & 8 & 17 & 1 & 2 & 1 & 2 \\
\hline $\begin{array}{l}\text { Public Health } \\
\text { Departments }\end{array}$ & 15 & 33 & 13 & 28 & 13 & 28 & 4 & 9 & 1 & 2 \\
\hline $\begin{array}{l}\text { S chool Counselling } \\
\text { Servi ces }\end{array}$ & 8 & 17 & 9 & 20 & 11 & 24 & 17 & 37 & 1 & 2 \\
\hline $\begin{array}{l}\text { Special Education } \\
\text { Programs }\end{array}$ & 7 & 15 & 3 & 7 & 8 & 17 & 22 & 48 & 6 & 13 \\
\hline $\begin{array}{l}\text { Youth Service } \\
\text { Bureaus }\end{array}$ & 34 & 74 & 7 & 15 & 3 & 7 & 2 & 4 & 0 & 0 \\
\hline $\begin{array}{l}\text { Crlpped Chlldren's } \\
\text { Division (Portland) }\end{array}$ & 8 & 17 & 4 & 9 & $i 1$ & 24 & 18 & 39 & 5 & 11 \\
\hline $\begin{array}{l}\text { University of Oreson } \\
\text { Medical School Child } \\
\text { Psychiatry Outpatien } \\
\text { Clinic }\end{array}$ & 117 & 37 & 15 & 33 & 8 & 17 & 4 & 9 & 2 & 4 \\
\hline $\begin{array}{l}\text { Private Treatment } \\
\text { Centers } \\
\end{array}$ & 22 & 48 & 16 & 35 & 7 & 15 & 1 & 2 & 0 & 0 \\
\hline State Hospltals & 34 & 74 & 10 & 22 & 2 & 4 & 0 & 0 & 0 & 0 \\
\hline Private Hospitals & 31 & 67 & 13 & 28 & 1 & 2 & 1 & 2 & 0 & 0 \\
\hline other & 39 & 85 & 0 & 0 & 3 & 7 & 3 & 7 & 1 & 2 \\
\hline Total & 24 & & 188 & & 170 & & 122 & & 26 & \\
\hline Mean & 18 & 39 & 10.2 & 23 & 9 & 20.5 & 6.7 & 14.6 & 1.4 & 3.1 \\
\hline
\end{tabular}


TABLE VIII

REFERRAL RESOURCES USED BY PEDIATRICIANS (2)

\begin{tabular}{|c|c|c|c|c|c|c|}
\hline & \multicolumn{2}{|c|}{$\begin{array}{l}\text { Low } \\
\text { Frequency }\end{array}$} & \multicolumn{2}{|c|}{\begin{tabular}{|l|} 
Moderate \\
Frequency
\end{tabular}} & \multicolumn{2}{|c|}{\begin{tabular}{|l|} 
Htgh \\
Frequency \\
\end{tabular}} \\
\hline & No. & $\%$ & No. & $\%$ & No. & $\%$ \\
\hline Children's Services Division & 18 & 39 & 26 & 57 & 0 & 0 \\
\hline Mental Health C1inics & 13 & 28 & 30 & 65 & 3 & 6.5 \\
\hline Family Counsellng Services & 24 & 52 & 22 & 48 & 0 & 0 \\
\hline Private Psychiatrists & 18 & 39 & 27 & 59 & 1 & 2 \\
\hline Private Psychologists & 18 & 39 & 25 & 54 & 3 & 6.5 \\
\hline $\begin{array}{l}\text { Private Practicing } \\
\text { Social Workers } \\
\end{array}$ & 39 & 85 & 6 & 13 & 2 & 4 \\
\hline Ministers & 38 & 83 & 8 & 17 & 0 & 0 \\
\hline Tuvenlle Courts & 37 & 80 & 9 & 19.5 & 1 & 2 \\
\hline Publ ic Heal th Departments & 28 & 61 & 17 & 37 & 1 & 2 \\
\hline School Counseling Services & 17 & 37 & 28 & 61 & 1 & 2 \\
\hline Speclal Education Programs & 10 & 22 & 30 & 65 & 6 & 13 \\
\hline Youth Service Bureaus & 41 & 89 & 5 & 11 & O. & 0 \\
\hline $\begin{array}{l}\text { Cripperi Chil dren's 'Division } \\
\text { (Portland) }\end{array}$ & 12 & 26 & 29 & 63 & 5 & 11 \\
\hline $\begin{array}{l}\text { University of Oregon Medical } \\
\text { School Child Psychiatry Outpatient. } \\
\text { cifnic }\end{array}$ & 32 & 69.5 & 12 & 26 & 2 & 4 \\
\hline Private Treatment Centers & 38 & 83 & 8 & 17 & 0 & 0 \\
\hline State Hospitals & 44 & 96 & 2 & 4 & 0 & 0 \\
\hline Private Hospitals & 44 & 96 & 2 & 4 & 0 & 0 \\
\hline other & 39 & 85 & 6 & 13 & 1 & 2 \\
\hline Tota1 & 510 & & 302 & & 26 & \\
\hline Mean & 28.3 & 61.5 & 16.8 & 36.5 & 1.4 & 3 \\
\hline
\end{tabular}


The first observation which can be made is that the general utillzation rate for all the referral resources is $10 \mathrm{w}$, with $61.5 \%$ average response for the low frequency use and an average of only $3 \%$ showing a high usage rate. Thpse resources whlch are used for referral with moderate to high frequency by more than half the respondents are (in. déscending order of usage):

Special School Education Programs

Crippled Children's Division

School Counselling Programs

Mental Health Clinics

Private Psychiatrists

Private Psychologists

Chilaren's Services Division

Among these, only the special education programs show a significant rate of "high frequency" use. On the other hand, there are five resources which are used never by more than half the respondents. Among the least used are the following facilities, which show an $80 \%$ or higher rate of "1ow frequency"! use. (shown in descending order usage rate):

Juventle courts

Ministers

Private treatment centers

Private practicing social workers

Youth service bureaus

State hospitals

Private hospitals 
It is of special interest that pediatricians appear to use the schools as a resource with greater frequency than any other. The mental health clintcs and Children's Services Division are the only public resources which seem to be used with any signiflcant frequency. The usage of. both psychiatrists and psychologists is moderate but apparently not as great as when they are being used as a consultation resource or as a hypothetical treatment resource for the respondent's own famliy.

V. SATISFACTION WITH REFERRAL RESOURCES

In organizing the data for this section, I have presented it in two forms. The first table is the same one used in the questionnaire with the exception of an added column which shows the "no response tabuiations." It offers the advantage of Identifying quickly the extremes; namely, columns 1 and 4 which show satisfaction with both quantity and quality and column 4, whlch shows dissatisfaction with both measures. The second table, on the other hand breaks the data down into two general groups which show dissatisfaction varsus satisfaction and two subgroups in eech which identify the parameter of quantity and quality. This table also shows the percentages of each. These two tabjes appear in the two pages following. 
TABLE IX

SATISFACTION WITH REFERRAL RESOURCES (1)

\begin{tabular}{|c|c|c|c|c|c|c|c|c|c|c|}
\hline \multirow[t]{2}{*}{ Resource } & \multicolumn{2}{|c|}{$\begin{array}{l}\text { Quality } \& \\
\text { quanti ty } \\
\text { are sats- } \\
\text { factory }\end{array}$} & \multicolumn{2}{|c|}{$\begin{array}{l}\text { Quality is } \\
\text { sat I sfactory } \\
\text { but quantity } \\
\text { is adequate }\end{array}$} & \multicolumn{2}{|c|}{$\begin{array}{l}\text { Quality is } \\
\text { unsatis- } \\
\text { factory hut } \\
\text { quant t ty } \\
\text { is adequate }\end{array}$} & \multicolumn{2}{|c|}{$\begin{array}{l}\text { Nelther } \\
\text { quality nor } \\
\text { quantl ty is } \\
\text { satis- } \\
\text { factory }\end{array}$} & \multicolumn{2}{|c|}{$\begin{array}{l}\text { No Re- } \\
\text { sponse }\end{array}$} \\
\hline & No. & $\%$ & No. & $\%$ & No. & $\%$ & No. & $\%$ & No, & $\%$ \\
\hline $\begin{array}{l}\text { Children's } \\
\text { Services Div. }\end{array}$ & 15 & 44 & 7 & 22 & 5 & 16 & 5 & 16 & 15 & 32 \\
\hline $\begin{array}{l}\text { Mental Health } \\
\text { clinics }\end{array}$ & 7 & 21 & 13 & 39 & 5 & 15 & 8 & 24 & 14 & 30 \\
\hline $\begin{array}{l}\text { Family Counseling } \\
\text { Services }\end{array}$ & 12 & 46 & 8 & 31 & 4 & 15 & 2 & 8 & 21 & 45 \\
\hline $\begin{array}{l}\text { Private } \\
\text { Psychiatrists }\end{array}$ & 25 & 69 & 4 & 11 & 7 & 19 & 0 & 0 & 11 & 23 \\
\hline $\begin{array}{l}\text { Private } \\
\text { Psychologists }\end{array}$ & 19 & 63 & 5 & 17 & 8 & 21 & 0 & 0 & 17 & 36 \\
\hline $\begin{array}{l}\text { Private Soclal } \\
\text { Workers } \\
\end{array}$ & 13 & 62 & 3 & 14 & 5 & 24 & 0 & 0 & 26 & 55 \\
\hline Ministers & 14 & 67 & 1 & 5 & 4 & 19 & 2 & 10 & 26 & 55 \\
\hline Juvenile Courts & 13 & 59 & 2 & 9 & 3 & 14 & 4 & 18 & 25 & 53 \\
\hline $\begin{array}{l}\text { Publ ic Health } \\
\text { Departments }\end{array}$ & 13 & 45 & 8 & 21 & 4 & 14 & 2 & 7 & 18 & 38 \\
\hline $\begin{array}{l}\text { School Counseling } \\
\text { Services }\end{array}$ & 9 & 39 & 8 & 23 & 7 & 20 & 11 & 31 & 12 & 26 \\
\hline $\begin{array}{l}\text { Special Education } \\
\text { Programs } \\
\end{array}$ & 10 & 29 & 10 & 29 & 5 & 15 & 9 & 26 & 13 & 28 \\
\hline $\begin{array}{l}\text { Youth Service } \\
\text { Bureaus }\end{array}$ & 6 & 50 & 3 & 25 & 2 & 17 & 1 & 8 & 35 & 74 \\
\hline $\begin{array}{l}\text { Crippled Children's } \\
\text { Division (Portlan }\end{array}$ & d) 27 & 87 & 1 & 3 & 3 & 10 & 7 & 23 & 16 & 34 \\
\hline $\begin{array}{l}\text { S. of Oregon Medice } \\
\text { School Child Psy- } \\
\text { chlatry Outpatient } \\
\text { Clinic }\end{array}$ & $\begin{array}{l}a 1 \\
t \\
+14\end{array}$ & 54 & 6 & 23 & 4 & 15 & 2 & 8 & 21 & 45 \\
\hline $\begin{array}{l}\text { Private Treatment } \\
\text { Centers } \\
\end{array}$ & 11 & 58 & 5 & 26 & 3 & 16 & 0 & 0 & 28 & 60 \\
\hline State Hospltals & 9 & 60 & $i$ & 7 & 4 & 27 & 1 & 7 & 32 & 68 \\
\hline Private Hospltals & 9 & 69 & 1 & 8 & 2 & 15 & 1 & 8 & 34 & 72 \\
\hline Mean & & 54 & & 18 & 1 & 17 & & 11 & & 46 \\
\hline
\end{tabular}


TABLE $X$

SATISFACTION WITH REFERRAL RESOURCES (2)

\begin{tabular}{|c|c|c|c|c|c|c|c|c|}
\hline \multirow{3}{*}{ Resource } & \multicolumn{4}{|c|}{ Satisfied } & \multicolumn{4}{|c|}{ Dissatisfied } \\
\hline & \multicolumn{2}{|c|}{ Quality } & \multicolumn{2}{|c|}{ Quant1 ty } & \multicolumn{2}{|c|}{ Qua11ty } & \multicolumn{2}{|c|}{ Quant1ty } \\
\hline & & $\%$ & No. & $\%$ & No. & $x$ & No. & $\%$ \\
\hline $\begin{array}{l}\text { Children's Services } \\
\text { Division }\end{array}$ & 22 & 69 & 20 & 63 & 10 & 31 & 12 & 38 \\
\hline $\begin{array}{l}\text { Mental Health } \\
\text { c1inics }\end{array}$ & 20 & 61 & 12 & 36 & 13 & 39 & 21 & 64 \\
\hline $\begin{array}{l}\text { Family Counseling } \\
\text { Services }\end{array}$ & 20 & 77 & 16 & 62 & 6 & 23 & 10 & 38 \\
\hline $\begin{array}{l}\text { Private } \\
\text { Psychlatrists }\end{array}$ & 29 & 81 & 32 & 89 & 7 & 19 & 4 & 11 \\
\hline Private Psychologists & 24 & 80 & 27 & 90 & 8 & 27 & 5 & 17 \\
\hline $\begin{array}{l}\text { Private Social } \\
\text { Workers }\end{array}$ & 16 & 76 & 18 & 86 & 5 & 24 & 3 & 14 \\
\hline Ministers & 15 & 71 & 18 & 86 & 6 & 29 & 3 & 14 \\
\hline Juvenile Courts & 15 & 68 & 16 & 73 & 7 & 32 & 6 & 27 \\
\hline $\begin{array}{l}\text { Publ ic Health } \\
\text { Departments }\end{array}$ & 21 & 72 & 17 & 59 & 6 & 21 & 10 & 34 \\
\hline $\begin{array}{l}\text { School Counseling } \\
\text { Services }\end{array}$ & 17 & 49 & 16 & 46 & 18 & 51 & 19 & 54 \\
\hline $\begin{array}{l}\text { Specla1 Education } \\
\text { Programs } \\
\end{array}$ & 20 & 59 & 15 & 44 & 14 & 41 & 19 & 56 \\
\hline $\begin{array}{l}\text { Youth Service } \\
\text { Bureaus }\end{array}$ & 9 & 75 & 8 & 67 & 3 & 25 & 4 & 33 \\
\hline $\begin{array}{l}\text { Crippled Children's } \\
\text { Division (Portland) }\end{array}$ & 28 & 90 & 30 & 97 & 10 & 32 & 8 & 26 \\
\hline $\begin{array}{l}\text { O. of Oregon Medical } \\
\text { School Child Psychi- } \\
\text { atry Outpatient } \\
\text { C1lnic }\end{array}$ & 20 & 65 & 18 & 69 & 6 & 23 & 8 & 31 \\
\hline $\begin{array}{l}\text { Private Treatment } \\
\text { Centers }\end{array}$ & 16 & 84 & 14 & 74 & 3 & 16 & 5 & 26 \\
\hline State Hospltals & 10 & 67 & 13 & 87 & 5 & 33 & 2 & 13 \\
\hline Erivate Hospltals & 10 & 77 & 11 & 85 & 3 & 23 & 2 & 15 \\
\hline Mean & & 72 & & 71 & & 29 & & 30 \\
\hline
\end{tabular}


In looking at the data, the "no response" columns provide information that is almost as useful as the other data, One is first struck by the high tate of what could be called "no opinton." In general, those resources whlch show a hlgh rate of "no oplnion" are also those 11 sted on page 65 which show the lowest usage rate. The same resources show elther an average or lower than average "dissatlsfaction with quality" response rate. What this suggests then, is that pediatriclans have no opinion about these resources because they don't use them. Th1s becomes circular, however, for the reason they don't use them doesn't appear to relate to thelr dissatsifaction with these resources but rather to their unfamiliarity with them. A high rate of "no opinion" about other resources that are used more frequently, however, probably indicates a low level of followup or feedback communtcation with the referral resources after the referral has been made. Some lengtfiy, thoughtful comments offered at the end by respondents indlcated the frustration with not learning about the outcome of referrals mede to public agencies. Those resources which show n low "no opinion" response rate also correspond generally to those whlch showed a higher usage rate from the previous charts. One resource, private psychiatrist shows a particularly low "no opinion response rate," even though it ranks about fifth for usage rate. Most simple stated, this means that pediatricians have a lot of opinions about psychiatrists. It may mean that feedback between them is better than average as well.

When one looks at how psychiaurists fared in the several measure of satisfaction and dissatisfaction, respondents rank them second only to Crippled Children's Division In their satisfaction with both quality 
and quantity. of particular interest are those resources which show a relatively high usage rate but recelve a low rating for el ther quality or quantity. Among these are the following, which show a higher than average response rate for "dissatisfaction with quality:"

Dissatisfaction with Quality

School counseling services $51 \%$

Special education programs $\quad 41 \%$

Mental health clinics $\quad 39 \%$

(Mean dissatisfaction with all resources $=29 \%$ )

The high digsatisfaction with both mental health clinics and the schools is echoed by numerous comments made in response to the openended questions at the end of the questionnalre. The dissatisfaction with the schools is amplified by frequent comments that suggest that the schools ought to be the logical place to co-ordinate many key mental health activities, including recognition of the problem, education of parents, co-ordinated and continuous followup for the child. The frustration appenrs to be higher in this case because of what most respondents seem to feel should be possible.

Most of the corments about the mental health clinics indicate a belief that the services of the clinics are not oriented to children. It is interesting to recall that in its 1971 budget request, the Mental Henlth Division included as one of its requests the speciflc recommendation that the mental heajth clinics assistin the integration of mental health services in the weil-child clinics and in the pediatricians' daily practice. 65

\footnotetext{
65inental Health Program Eor Children," Children's Services Section, Dregion Menital Health Division 1971-73 Budget Request, (Dec. 1, 1970), P. 7.
} 
At the same time, respondents show a higher than average dissatisfaction with the quantity of these resources. The rate shom for mental health clinics is particularly striking. Included in the following list are also some of the other resources which show a signiElcantly higher rate in this column:

Dissatisfaction with Quantity

$\begin{array}{ll}\text { Mental health clinics } & 64 \% \\ \text { Special education programs } & 56 \% \\ \text { School counseling services } & 54 \% \\ \text { Family counseling services } & 38 \% \\ \text { Children's Services Division } & 38 \% \\ \text { (mean }-30 \% \text { ) }\end{array}$

What this seems to indicate is considerable frustration and dissatisfaction with most of the puhlic service facilities; in other words, those that, the general public can afford and would most 11 kely contact. There aren't enough of those resources pediatricians seem to be saying and those that do exist aren't good enough. They do in fact say this very clearly in their comments at the end. Making frequent reference to inaccessible or unavallable resources for low-income people. VI. SUMMARY

To summarlze some of the conclusions that have already been drawn Erom the data, the numbers of childnen who are seen by pediatriclans as mentally or emotionally disturbed is not as high as might be expected and may represent underreporting or an unwillingness to label problems as "mental health" problems. The following comments can be made. It would seem that a high percentage of pediatricians see themselves as providing treatment for mentally and emotionally dis. 
turhed chlidren. Most of them use consultation services in doing so. contacts with outalic resources for consultation are domlnated by private theraplats, efther psychologists or psychiatrists. Treatment refernals seem generally infrequent, as indlcated by the responses to both No, 4 and No, 6 . When made, however, they seem to be divided amnng private therapists, Crlppled Children's Division, school programs and mental health clinics. This is strikingly similar to a survey done in Rhode Island, whlch showed that pediatricians in that state made the most frequent referrals to private psychiatrists, mental health clinics and child development centers. 60 Satisfaction' is greatest with the former two while dissatisfaction with the latter two, particularly as amplified by the written comments at the end, is considerable. Trust and faith in competence seems to be most vested In the private theraplsts, particularly in the psychiatrists, although there may be some professlonal barrlers to working with them In a consul tative relationship. The interest expressed in the develop. ment of school programs, especialiy in the area of prevention or posi. tive mential health is quite high. Perhaps in 1 ine with this, more tespondents feit that the age group of 10 - 14 reeded services more than the other age groups.

Use of most public services appears to be low, but the data also suggests that there is a lack of famlliarity with what does exist. One pediatrician suggested that there should be programs in the community to acquaint. the physician with what is avaliable in the local community,

${ }^{66}$ Jaseph J. Bevilacqua, "Position Statement' on the Planning of Mental Health Services for the Children \&. Youth of Rhode Island," Dept. Qf Methe Retarsh \& Hospi. Div. of M.H., (Jan. 1975, unpubl I shed report), P. 196 . 
Along with Its cost to the patient. Perhaps one of the most important conclusions that can be drawn from thls data - taken together - is that pediatricians see themselves as very involved with the treatment process of mental1y and emotiona11y disturbed children. Offering more resources for these chlldren may not be the way to maximize the usefulness of the pediatrician. Training him in the appropriate use of referrals (along with a thorough grounding in what is avallable) together with good training and supportive services to help him do the job of therapy when it is approprlate (and which he is apparently already dolng) may have a greater ultimate yleld. The next chapter will explore the pediatric training program in Oregon and the extent to which it prepares the young pediatrician to deal with the mental health problems that have been under discussion in this chapter: 
A quick perusal of both pediatric and psychiatric ilterature reveals a long-standing recognition that pediatricians occupy a key position in the general realm of dealing with mental health problems of children. Among the thick volumes included on the shelves of a pediatric library in a training institution are titles such as: Psychlatry for the Pedlatriclan, Management of Emotional Disorders in Pediatric Practice, Child Psychiatry and the General Practitioner. The relationship between the pediatrician and the psychiatrist or child psychiatrist has long been a difficult, though often fruitful one. Each has often been preoccupled with consalidating his own professional identity and collaboration has often been sacrifled to both professional jealousies or to an unwillingness to invade each other's a rea of expertise. In 1952, the Group for Advancement of Psychiatry made a spectal study of these issues resulting in a report titled, "The Contribution of Child Psychiatry" to Pediatric Training and Practice." Many of the difficulties for the pediatrician attempting to gain some mastery of child psychiatric issues which are discussed in this report relate directly to the training program for pediatricians and are certainly current today. According to the author of one of the texts previously mentioned, "one of the most common complaints of the practicing pediatrician about his own earlier training is that it did not prepare h1m to deal with the emotionally disturbed child and his faml1y." 67

67Fingh, Stuart and John F. McDermott, Psychiatry for the Ped1atrlclan (New York: $W, W$, Nortion \& Co., Inc., 1970), P.12. 
Because the family pediatriclan is very often the first person sought for help in dealing with the emotlonal problems of a child, the way he manages these contacts is a critical factor in how the family manages the problem. His assets consist of knowing the entire family and his acqualntance with the developmental history of the child. Also, he is less threatening to the family than outsiders. 68 How much he is able to capitalize upon this natural advantage is then a function both of natural temperament and good training. As the author of one comprehensive state plan observed: "basic to any competency,... is an ability to identify potential problems in children and perhaps even more importantly, to adequately deal with the needs and feelings of children and their families." 69 The importance of making a good diagnosis is obviously a key part of the young pediatricians' ability to deal with these problems and should be an important part of his training. In spite of the fear expressed by some psychiatrists that such training will lead the pediatrician into areas beyond his expertise, according to at least one writer, this need not be the case: "the non-psychiatrist will not be overambitious to make the exact diagnosis of the emotional disturbances but will rather evaluate the situation to determine the child's need for specialized psychiatric attention." 70

68 Adam J. Krakowski \& Dante A. Santora, Child Psychiatry and the General Eractitloner (Springfield, I11.: Char 1es C. Thomas, 1962), P. 5.

${ }^{69} \mathrm{Joseph} \mathrm{J}$. Bevilacqua, "Position Statement on the Planning of Mental Health Services for the Chl ldren \& Youth of Rhode Island," Dept. of M. H., Retard. Hosp., Div, of MaH., (Jan. 1975, unpubl ished report), P. 102.

70 Adam J. Krakowski \& Dante A. Santora, Chlld Psychiatry and the General Practitioner (Sipringfleld, I11.: Charles C. Thomas, 1962), P. 5. 
In general, pediatric training in mental health issues probably concentrates on this area of recognition and diagnosis. Unfortunately, they may overlook other areas which contrlbute just as signiflcantly to the pediatrician's ultimate ease in dealing with these prob1 ems. As one writer observed, "It is extremely rare to find a pediatrician who has elther the time or training to do direct psychotherapy with children. ${ }^{71}$ what is needed, however, is not training to turn pediatriclans into child psychlatrists. As the same writer goes on to say, "The average doctor, even if he is convinced that the patient's problems are purely emotional feels insecure in dealing with them. He wonders what he should talk about, what questions to ask, how to respond to parents' questions, and how much of their family life he should leave alone." 72 What this seems to imply, then, is that a training program should address itself to such skills as interviewing techriques but also to subtler Interpersonal and intrapersonal issues such as use of the self, countertransference reactions and management of personal anxiety.

Another area which very often recelves little formal attention in a training program is the effective use of referrals. This involves not only the recognition of when a referral is appropriate but also an understanding of what resources are avallable and finally, the ski1lful managenent of the entire referral process. One writer speaks with particular asperity about the importance of the way in which this

$71_{\text {Finch, Stuart and John F. McDermott, Psychiatry for the Pedi- }}$ atrician (New York: W.W. Norton \& Co., Inc., 1970), P. 205.

72 Ibid.,. P. 209. 
process is handled.

"The mannet of handling the child and his parents by the nonpsychiatrist may largely shape the entire aspect of referral, if such is needed, and the future relationship between the patient, his family and the psychiatric facility.

"The proper technique of referral is important... The physician who does not accept the concept of emotional 111ness, who may use sarcastic methods of referral, who cannot well mask his own rejection of the child, who is evasive about the reason for referral, telling the parents that he is referring the child for psychometrlc testing or nearological examination when he knows well that the child requires a thorough psychiatric evaluation, is a poor source of referral." 73

How, then, are some of these issues handled in Oregon's pediatric training program, the pediatric residency program at the University of Oregon Health Sciences Center? In approaching. these Issues, I hoped to gain the perspective of both the residents and of some of the staff. To do this, I sent a questionnalre to 011 of the residents asking them to rate the adequacy of training in several different areas and also to respond to a choice of several attitudinal statements descriptive of positions often taken by pediatricians. I asked them to indicate both their own attitude and how they viewed the attitude of the faculty. Finally, to learn about the basic framework of the training program and to gain a perspective on the attltude of the faculty toward mental heaith lssues in the training program, I conducted several interviews, one with a member of the pediatric faculty, and one with member of the chlld psychiatry department, who had formerly been in practice as a pediatrician.

The pediatric training program at the University of Oregon Health

${ }^{73}$ Adam J. Krakowski \& Dante A. Santora, Child Psychiatry and the General Practitioner (Springfield, I11.: Charles C. Thomas, 1962), P. 5. 
Sclences Center is in a state of transition as are most of the trainIng programs throughout the nation. Within the last few months, the American Board of Pediatrics has issued a set of standards which tightens all the training programs, requiring them all to develop their training program into a three year graduated unit which will result in the following general structure:

Year 1: General introduction and rotation through classical inpatient and outpatient clinics.

Year 2: A series of 6 week electives, possibly including neropsychlatry.

Year 3: Three-month elective, supervision of first year residents and 12 weeks In a child health clinic.

The general affect of this, according to the faculty member interviewed, will be to structure in certain subspecialties while reducing much of the flexibility for concentrating on or omitting some of them. 74 Up until this time there has been no formal exposure to child mental health issues and no cumiculum content specifically deslgned to cover the emotional and psychological development of chlldren. These areas are handled by special seminars and grand rounds. Acconding to the faculty member interviewed, there is much avallable if the pediatric resident cares to seek it out. Recently, one of the pediatrlc residents did an extra year through the child psychiatry department. One of the members of the child psychiatry department has for several years had one pediatric resident assigned to him for a three month period and, meeting with him for one hour a week to discuss a

74 Most of information about training program gathered from Dr. John Isom. 
case Involving psychiatric problems. In addition, many residents have elected to do a rotation through C.D.R.C. whlch speciallzes in a dlagnostlc workup and treatment planning for bahavior disorders.

When asked to comment upon how well he felt the residents were trained to diagnose mental and emotional disorders and to make appropriate referrals, the reply of the pediatric staff person interviewed was, "They'11 get the feel and flavor of how to deal with them, but then went on to say, "Even if every pediatrician were adroit at recognizing emotional problems; where would they refer them?" In general he semed to feel that pediatrics has overstepped its bounds in becoming too involved with child psychiatric issues. When asked to compare the pediatric training program at the University of Oregon Health and Science Center with other training programs he was familiar with, he replied that in his experience with five training programs, the one in oregon gave its residents greater experience in psychiatry than any other.

Another perspective was provided by a faculty member from the child psychiatry department. ${ }^{75}$ In his view, the pediatric training program in Oregon has less psychiatric input than average. He felt thet the greatest deficlences in tralning were in the areas of child development and in interviewing skills. "Most pediatric practice is made up of advice giving rather than real 1istening," he observed. He felt strongly that the. important changes would have to begin with the training program. He did feel that the younger residents coming

\section{${ }^{75}$ Following information and opinions gathered from interview} with Dr. Herb Woodcock. 
into the programs were showing more interest in the field and were demanding to be taught more. As was observed back in 1952 by the Group for the Advancement of Psychiatry Comnittee, however, "The broadening of the training program of the future pediatrician to include pertinent principles and practices from child psychiatry can be achleved only when the pediatric personnel of the hospital really wish it." 76 One step toward this goal may be achieved beginning on July 15, 1976 when for the first time, all pediatric residents will have, during the course of their three year program, a six week rotation through chlld psychiatry.

In attempting to get some idea of how residents viewed their own training program, I sent a questionnaire to all fifteen residents. A copy of the questionnaire with the cover letter can be found in Appendixes $I$ and $M$. Out of the fifteen letters sent, I recelved thirteen back. Among those questioned, the numbers were almost evenly divided between those who had chosen an elective relating to the mental and emotional disorders of childhood (5) and those who had not (6). All who had elected them found them helpfui. One had not yet determined his electives for the next two years and another reported at iength that he had had two months of child psychiatry as part of a pediatric training program in Kansas City before coming to Oregon as a third year resident. In his view there is very little formal training in child psychiatry at the University of Oregon Health and Science Center.

76" The Contribution of Child Psychiatry to Pediatric Training and Practlce" GAP, Report 21 (Jan. 1952), P. 5. 
Results for question No. 3 are shown below:

TABLE XI

SATISFACTION WITH TRAINING

\begin{tabular}{|c|c|c|c|}
\hline 2 & Too little & Too much & Enough \\
\hline $\begin{array}{l}\text { Normal psychol ogl cal } \\
\text { devel opment of children }\end{array}$ & - & & 5 \\
\hline $\begin{array}{l}\text { b. Diagnosis of major psy- } \\
\text { chologi cal disturb- } \\
\text { ances of childhood }\end{array}$ & 10 & . & 3 \\
\hline $\begin{array}{l}\text { c. Management and treat- } \\
\text { ment of the chlld with } \\
\text { psychological disturb- } \\
\text { ance }\end{array}$ & 12 & & 1 \\
\hline $\begin{array}{l}\text { d. Use of consultative } \\
\text { services and referral } \\
\text { resources }\end{array}$ & 5 & & 8 \\
\hline
\end{tabular}

While the overall pattern is certainly one of feeling inadequately trained, the high emphasis on needing competency in management and treatment with the relatively lower feeling of need to be trained In use of consultation and making referrals suggests a proflle of the pediatrician who wants to do it all himself. A similar profile emerged to some extent from the results of the quesionnalre examined in chapter VI. It would be interesting to know how much this attitude corresponds to a kinds of neophyte optimism where all things seem possible. It might also be true that it requires a few years of private practice away from the sheltered atmosphere of a training institution to 1 earn the importance of being able to use consultations effectively and to make referrals smoothly.

The design of question No. 4 was such, that interpretations of results must be made carefully. Its intent was to pick up extremes and any discrepancies between the resident's attitude and the staff attitude as perceived by the resident. Because I did not include a statement which reflected an extreme attitude of, "I can do it al1 
myself without any help," the results are naturally biased. The

tabulations of the results are as follows:

a. In most cases of mental and emo-

\begin{tabular}{cc} 
Staff & Your \\
Attitude & Attitude \\
\hline
\end{tabular}

tional disorders of children, pedi-

atricians could provide primary

treatment if they utilized consulta-

tion services from mental hed th

professionals.

3

b. Pediatricians should be qualifled to handle mild behavior problems of childhood but should refer all serious mental and emotional disturbances to a qualifled mental health specialist.

c. Pediatricians have been stepping over their boundaries in trying to be all things to all people. The business of a pediatrician should be to treat the physical problems of children. Any problems which are not physical should be referred to a psychlatrist or other mental health specialist.

d. Pediatricians have been trying to ignore the mental and emotional problems of childhood for too long. They need more training to help them make accurate diagnoses and intelligent referrals when they are unable to provide treatment themselves.

e. Pediatriclans should be prepared to handie short term, acute psychiatric crises in children, such as those frequentiy found in an inpatient setting, but should refer all cases requiring 1 ong term treatment to a mental health specialist.
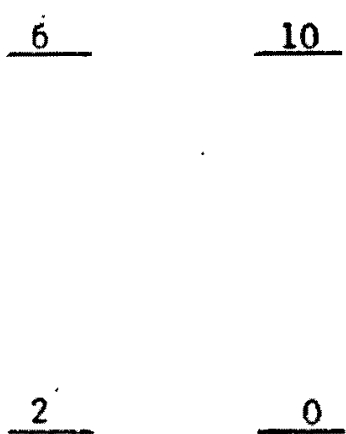

1 3

The only extremes indlcated were two responses to statement d, showing a bellef that staff attitude was that pediatrics should stay out of the business of child psychiatry. In general, the responses cluster around statements that indicete a definite commitment to providing services for children with emotional disturbances with a corresponding 
recognition of the need for help from mental health professionals. Perhaps the most important conclusion that must be drawn from nj) of the material presented in this chapter has to do with the im. portance of the training program. The pediatriclan can not escape the crucial position he is in with regard to the mental and emotional. problems of his young patients. How he chooses to handle himself in. that key position is partly a function of temperament but is probably permaniently shaped by the tralining he has - training which probably has its greatest impact in teaching a methodology of problem solving. At the present, at least, the majority of residents in training in oregon feel that they are being inadequately trained in many of the key areas which might condition problem solving to be more than a medical response. 
CHAPTER VIII

\section{SUMMARY}

In taking one final lobk at Oregon's movement thward comprehens!ve planntag for children, it is not easy to conclude with any 'tidy summation. To return to the premise of Chapter III, a state, no less than an individual is conditioned by its history, and oregon's history with regard to the development of programs for 1 ts mentally and emotionally disturbed chlldren has been complicated. Yet there are patterns which have interwoven through time, patterns which w111 probably repeat themselves through time and which will have a continuing effect on those tssues which have been ralsed in this paper. One way of describing these patterns would be to say that historlcally, Oregon has had moments of passion and promise imbedded in a conservative matrix of program development. This paper has highlighted few of the studies and experimental projects for children which have had periods of ascendancy. In general, however, development has proceeded in a doggedly local fashion. The comparison often made between an oregonlan and the rugged - and conservative - individunlist of Maine is perhaps an apt one. Oregon has never lacked for ideas nor for the data to support a varlety of programs. One rocalls that with regard to children's programs, Oregon has been called the hest studled state in the nation. Indeed, the Governonr's task force is at present engaged in studying models or planning mechanisms teveloped in other states.

Yet Oregon has not been ab1e to come up with a comprehensive mental health program for lts children. It presents a fascinating contrast to observe that when the state of Majne prioritized a com- 
prehenslve State Plan for Mentally and Emotionally Disturbed Children, It did so largely on tha basis of projections of the Joint Commlssion Peport wihnut the benefit of any statewlde studles of need. Yet to say that oregon has not done the same is not to impugn the public mindedness of its citizens but rather to imply merely that polltical process moves differently in oregon. I am not a politician nor proper1y a historican, but the events which mark Oregon's development in this area of children's programs are political and historlcal and to - ttempt to understand them outside of these dimensions is to risk the fallure of all future programs.

In general, the most inspirational successes in Oregon have been those which were on a small scale and had a strong local foundation. The traveling clinics of the 1930's achieved a remarkable level of multiple discipline involvement and seemed genuinely to galvanize problem solving at a community level. Yet in the 1960's, when the comprehensive community mental health center was offered as a national model for a community program, it was largely rejected by this state. The community mental health clinics have been somewhat more successful hut have certainiy falled in their mission to the state's children. The pilot project for emotionally disturbed chlldren undertaken in 1969 demonistrated a stunning model of how a truly comprehensive system can he hullt into the network of the community; but it was on a small scale and was ultimately emasculated by the lack of legislative fiscal support. At the same time, six treatment centers throughout the state seem to be alive and doing well; though they are lacking in financial support, probably because they were forced (through some of the accldents of financial exigencles recounted earlier) to develop as the 
sole responsibility of the community. Perhaps in recognition of this need for local planning and input from local cominumites, the State Mental Health Division sponsored local forums deslgned to provide Input into state planning. They were largely a fallure. Perhaps it should be no surprise that the one county that seemed to use the forum well - Multnomah County - was the one which paid most attention and gave most time to this process, of how people share information and help each other change. How, then can the dil emma be solved between entrenched local values and conservative process and an overriding priority to make needed change and advarces? Obviously, this is not a dilemma that invites a ready solution. Yet in terms of some of the issues that have been ralsed in this paper, such as the apparent determination of many pedlatricians to provide their own treatment to children with mental and emotional distunbance, or the apparent refusal of localities to be told by the state how to do their own 1ocal planning... these tendencles and others suggest that many of the solutions may have to butld on local models that maintain a respect for the informal processes of exchange which inform all helping interactions. Thls is not to say that it is possible to get anywhere without co-ordination, and responsibility and even ultimate authority, but it would appear that thls authority wili have to take form that is particularly sensitive to local coloration and nuance in order to be successful. Perhaps in Oregon, the now famous statement made by the Group for the Advancement of Psychiatry Committee in 1972 also applies: "Money alone cannot help children. The law alone cannot help children. It requires a vital commitment 
within commut ties to sort out what they have and what they want." 17

77"Crisis in Child Mental Health: A Critical Assessment," Group for the Advancement of Psychiatry, Report No.182, (February 1972), P. 124. 
APPENDIX A

CONTRIBUTIONS BY AND SUPPORT OF FIRST

CHILD GUIDANCE CIINIC IN OREGON

(December, 1931) 

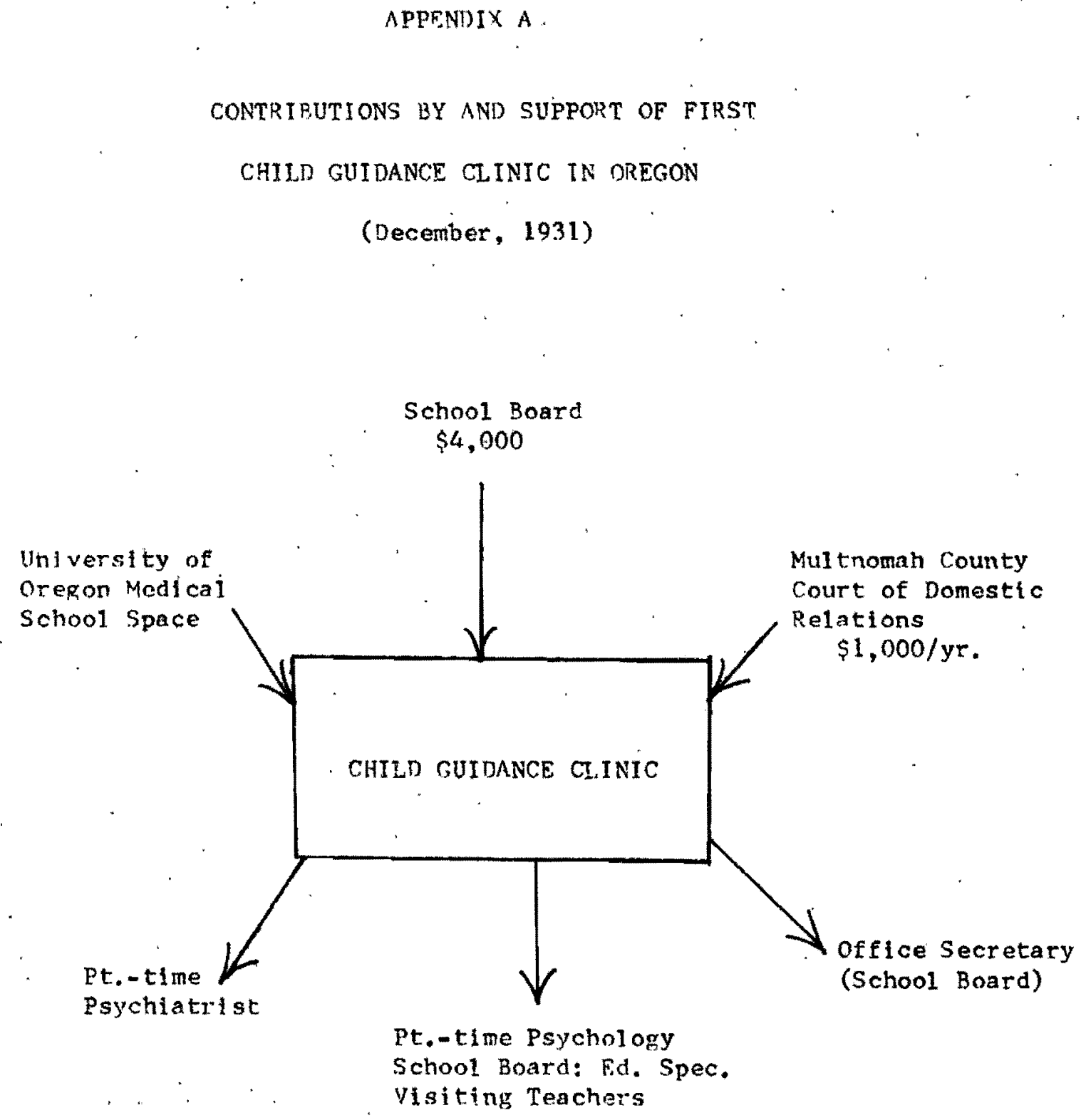


\section{NoOayo NI HITVaH TVINIW GIIHO gо \\ XUOZSIH ZHL NI SENZWOOO INYDIAINDIS}

g XIONGdd 


\author{
APPENDIX B \\ SIGNIFICANT DOCUMENTS IN THE HISTORY \\ OF CHILD MENTAL HEALTH IN OREGON
}

1. Oregon Governor's Committee, Oregon's White House Conference on Ch11d Health and Protection, May 1932.

2. Kirkpatrick, Milton, A Study of Child Guidance Services in Portland and the State of oregon with Special Reference to Ways in Which They Can be Improved, 1932.

3. Lewis, Martin C., Description of the Chlld Guidance Clinic Set-up and Suggested Expansion (Portiand) 1936.

4. Universlty of Oregon Medical School, A P1an for the Extension of the Chi1d Guidence clinic of the University of Oregon Medical Schoo1: to Communities in the State of Oregon, November 1936.

5. University of Oregon Medicai School, Child Guidance in Oregon: With Recommendations of the Governor's Special Committee, July 1, 1937.

6. East, Allan, Child Guldance Clinics in Small Communities of Oregon, 1939.

7. American Academy of Pediatrics, Child Health Services in Oregon, June, 1948.

(*)8. Oregon Governor's State Committee on Chlldren and Youth, Mental Health Services for Children and Youth, 1950.

9. Oregon Governor's State Comintere on Children and Youth, Health Services and Facilities for Childremin Oregon, 1952.

10. Division of Mental Health, First Report: Proposed Mental Hea1th Program for the Public Schools, August 1955.

11. White House Conference Comititees, Needed Serviceg for Oregon's Children: A Summary of Peports, 1959 .

12. Oregon Governor's state Committee on Children and Youth, A Look at Oregon's Children: Report to the Golden Anniversary White House Conference on Children and Youth, November 1959.

(*)13. Taylor, Eugene; Needed Services for Sevenly Emotionally Disturbed Children in Oregon, August 1964. 
14. Mental health Planning Bonrd for the Mental Health Division of the Oregon State Board of Control. The Ultimate Goal: A Plan tor Today. $\triangle$ Comprehensive Plan for a Mental Health Program in Oregon, 1965 .

15. Trei eaven, J.ll. A Residential Care Program for Chlldren and Adolescents with Severe Mental IIIness, Apri 1.966.

16. Oregon Governor's Committee on Children and Youth, Focus on Children: The Significant First Decade (Proceedings of the 1966 Oregon Conference on Children and Youth); December 1966.

17. Oregon Mental Heal th DIxision, Review of Mental Health Division Programs, December 1966.

(*)18. Oregon Mental Health Division, Draft of Purchase of Care Program: Psychlatric Services for Children, April $19 \overline{67}$.

(*) 19. Oregon Governor's Child Welfare Study Committee, Child Welfare Needs and Services in Oregon ("Greenlelgh Report"), December 1968,

(*)20. Oregon Mental Health Division, Pilot Program for Emotionally Disturbed Children, February 1969.

21. Jolnt Commission on Mental Health of Children, Inc., Crisis in Child Mental Health: Challenge for the 1970's, 1970.

(*)22. Oregon Governor's Committee on Youth, Recommendations of Professional Study Group on Report of the Joint Comission on Menta1 Hea1th of ChIIdren, Inc., Apri1 1970.

23. Oregon Mental Health Division, Proposal for a Children's Program, June 1970.

(t)24. Mental Health Division, Mental Health Program for Children, (Mental Health Division, 1971-73 Budget Request), December 1970.

(*)25. Portland City Club, Report on Services for Severely Disturbed Children in Oregon, March, 1971 .

26. Child Study and Treatment Section, Report of Activities, March 1973.

27. Oregon Mental Health Division, 1973 - A Turning Point for Mental Health Programs in Oregon, October 1, 1973 .

(*)28. League of Women Voters, Menta1 Health Services for Children and Youth in Oregon, Parts I \& II, September 1974. 
29. Oregon Mental Health DIvision, Proceedings of N.W. Regional Forum on Mental Heelth Services for Chlldren, September 1975.

(*) These publications have been of particular importance in the development of children's programs in the state. 

Route 2, Box 388

Aurora, Oregon 97002

March 15, 1976

Dear

I am presently engaged in a research project through Portland State University, as part of the requirements for a Master's Degree in Social Work. For the past five months I have been working with Tom Stern and Mary Hoyt of the Children's Study and Treatment Section in an effort to look at some aspects of the development of Children's Mental Health Services in the state of Oregon. I am currentiy interested in the ways in which some of the more informal caregivers (such as family doctors, pediatricians, ministers, etc.) are integrated into the formal Mental Health Delivery System. I have already sent a questionnaire to one such group of caregivers (1.e., pediatricians in the State of Oregon) designed to uncover such information as the extent of contact with emotionally disturbed children, the patterns of referral used, and utilization of and satisfaction with formal delivery service elements. ( 1 am enclosing a copy of this questionnaire for your information.) As it has long been a high priority of the CSTS to bring about an integration of all local resources, both formal and informal, this kind of information may be part of what is necessary to attain this goal.

As a part of the information I would 11 ke to obtain about rather hidden resources, I am interested in knowing how such people are involved in the planning process for Children's Mental Health Service Delivery. Since the State Planners depend largely on local planning and programming (such as the local forums now being given throughout the State) to provide input from these more informal sources, it is of special interest to me to know more about the way your forum is being planned and executed (or was planned, if you have already given it). As the information you provide me will give me some im-. portant pieces of the total picture I hope to make avallable to Tom and Mary and other state Planners, I hope you can take the time to answer the questions on the attached sheet.

Yours sincerely,

Kristin S. Angell

Enclosure 
1. Whom did you speciflcally contact or invite to your reglonal forum (1ist by discipline or agency rather than by name)?

2. The suggested format for information gathering did not provide a place for the agency or discipline of the respondent. Did you have any way of finding out what agencles or disciplines were represented?

Do you believe there were any important gaps in the representation? If so, do you have any explanation for them?

3. Did you feel that the input of your forum was dominated by any single professional or interest group?

4. Did you find the recommended format useful for elliciting infor. mation at your forum?

Do you have any criticisms of it?

5. Please describe the major difficulties you had to overcome in bringing about your regional forum.

6. Do you feel that reglonal forums such as these are an effective way of making local needs known to state level planners?

Do you have any suggestions for improving this process?

7. Do you feel that your forum was received positively by those im attendance? 
a XICNGdd 


\section{CONTENT FOR REGIONAL FORUMS}

In an effort to collect similar Information from each of the Reglonal Forums, the attached formats have been developed by our planning committee.

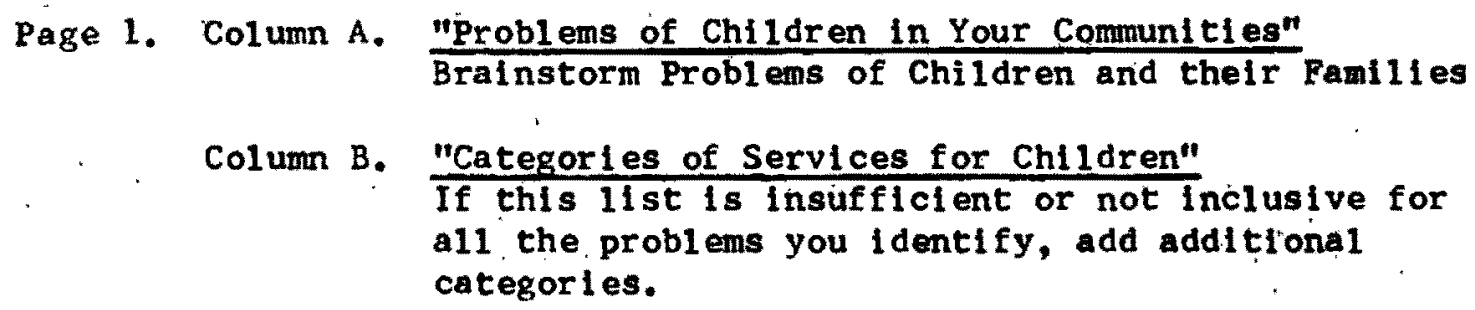

Page 2. F111 out one sheet for each category of service.

1. The 5th colunn "Phase in Time to Develop NeededProgram" should be stated by the Bleninial Year the new programs should be added (1:e.: 1977 or 1979 or 1981 ).

2. The last column "Amount of Community Mental Health Program Support Needed" - refers to amount of fiscal support.

An example has been enclosed.

Page 3. In order to help local programs and state offices prepare plans, programs whlch need to be expanded or newly developed are prioritized.

For further information or clarification of these forms, please contact your regional mental health specialist or Tom Stern $(378-2460)$.

MHD: $\operatorname{TOS} 12 / 17 / 75$ 
A XIanadd

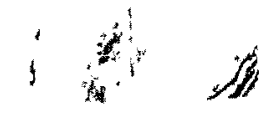


(A)

Problems of Children

in your

Communities

(List)
(B)

Categories

of Services

for Chlldren

(Complete this List)

\begin{tabular}{ll}
\hline Advocacy & Prevention \\
Screening \& Early Identification & Emergency \\
& Dlagnostic \\
& Out-patient \\
& Day Treatment \\
& Residentiai Treatment \\
Hospital & Consultation \\
Case Coordination \\
Research \& Evaluation \\
Planning
\end{tabular}


1

o XIaN3dd $\forall$ 
CATEGORY OF SERVICE:

DATE:

AGENCY TO COORDINATE THIS CATEGORY OF SERVICE: COUNTIES :

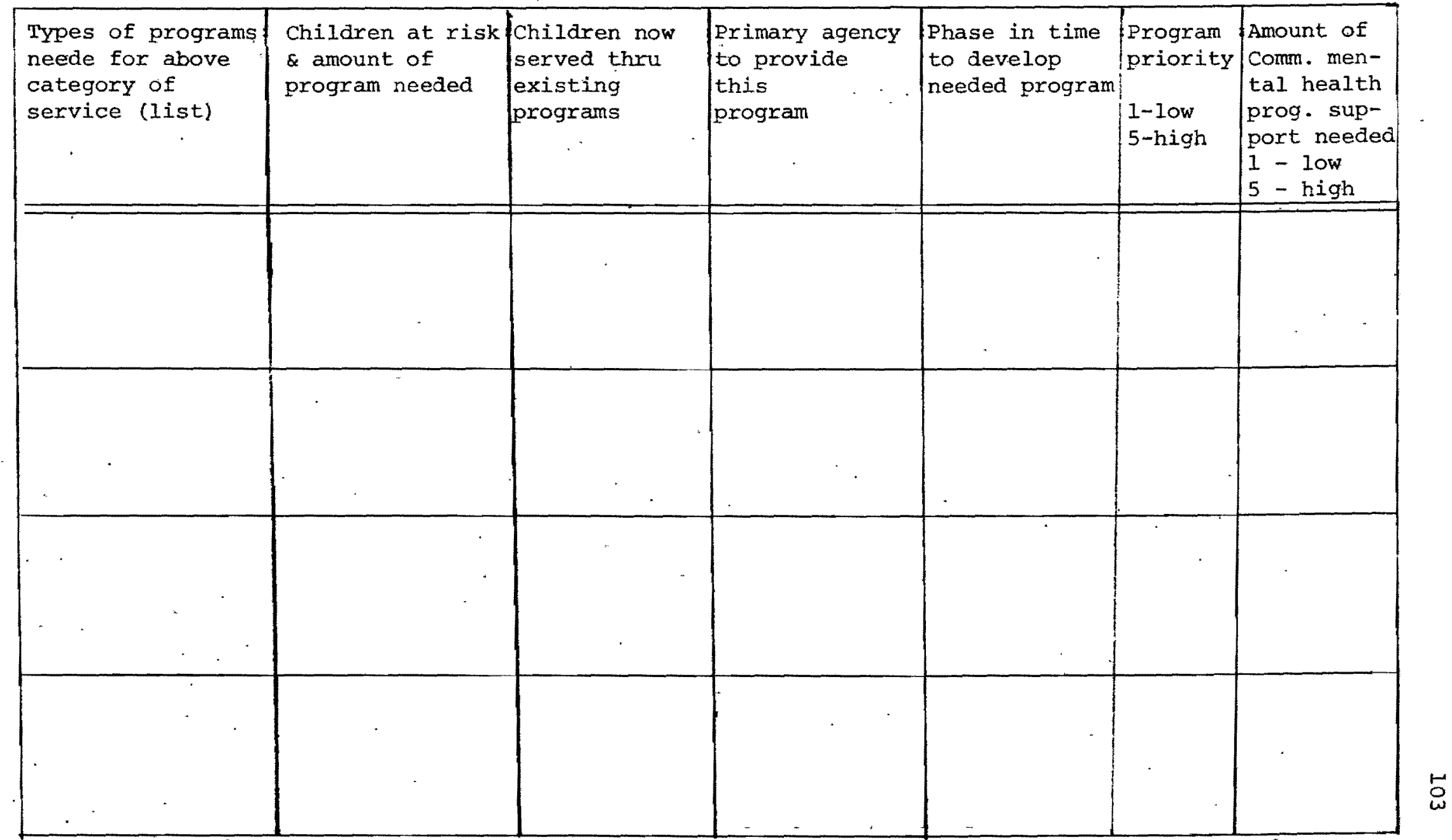




\section{H XIaNঊddV}


PRIORITIZATION

OF PROGRAMS WHICH NEED TO BE EXPANDED

OR NEWLY DEVELOPED

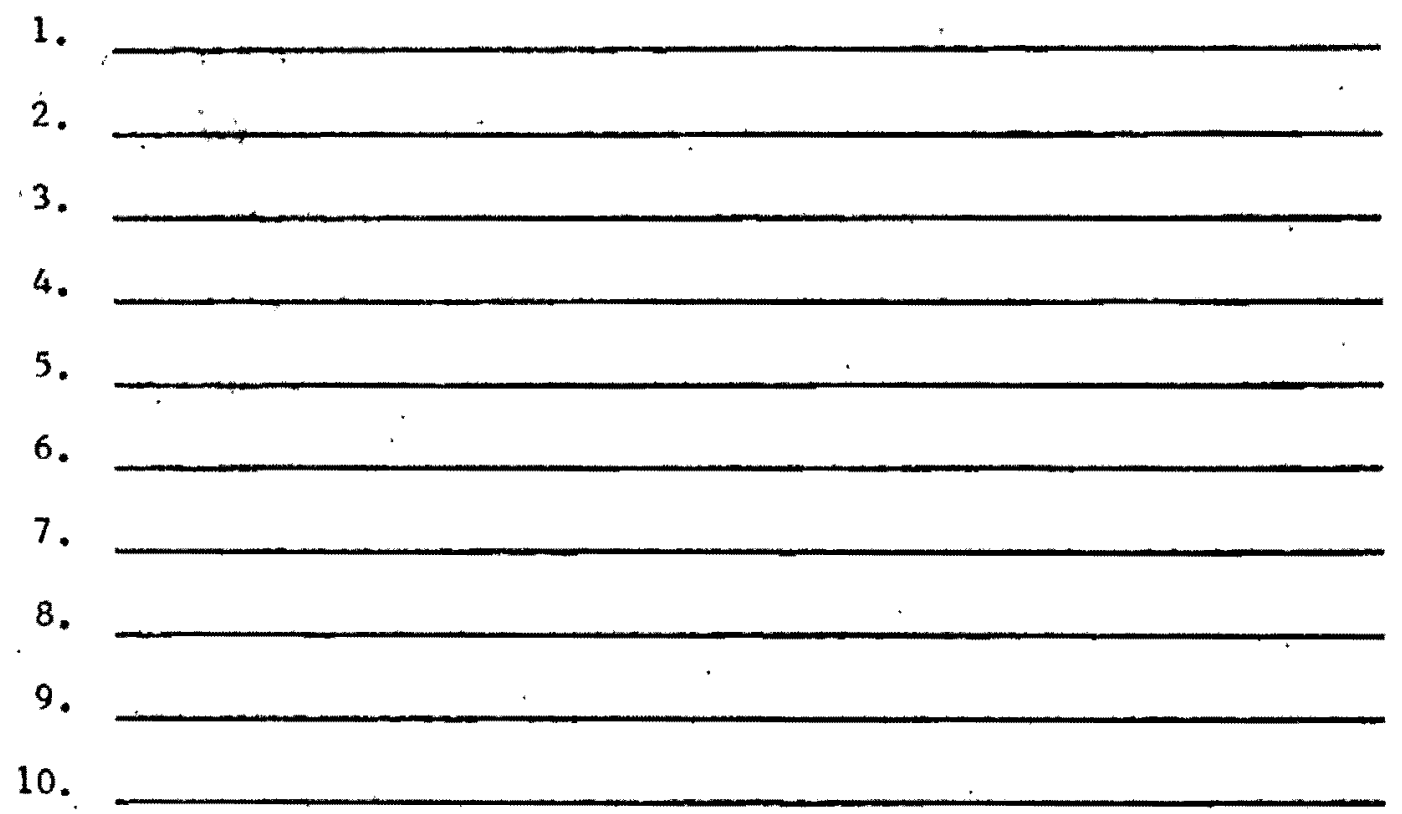

DATE:

COUNT IES:

MHD:TOS 12/75. 
I XIGNGddV 


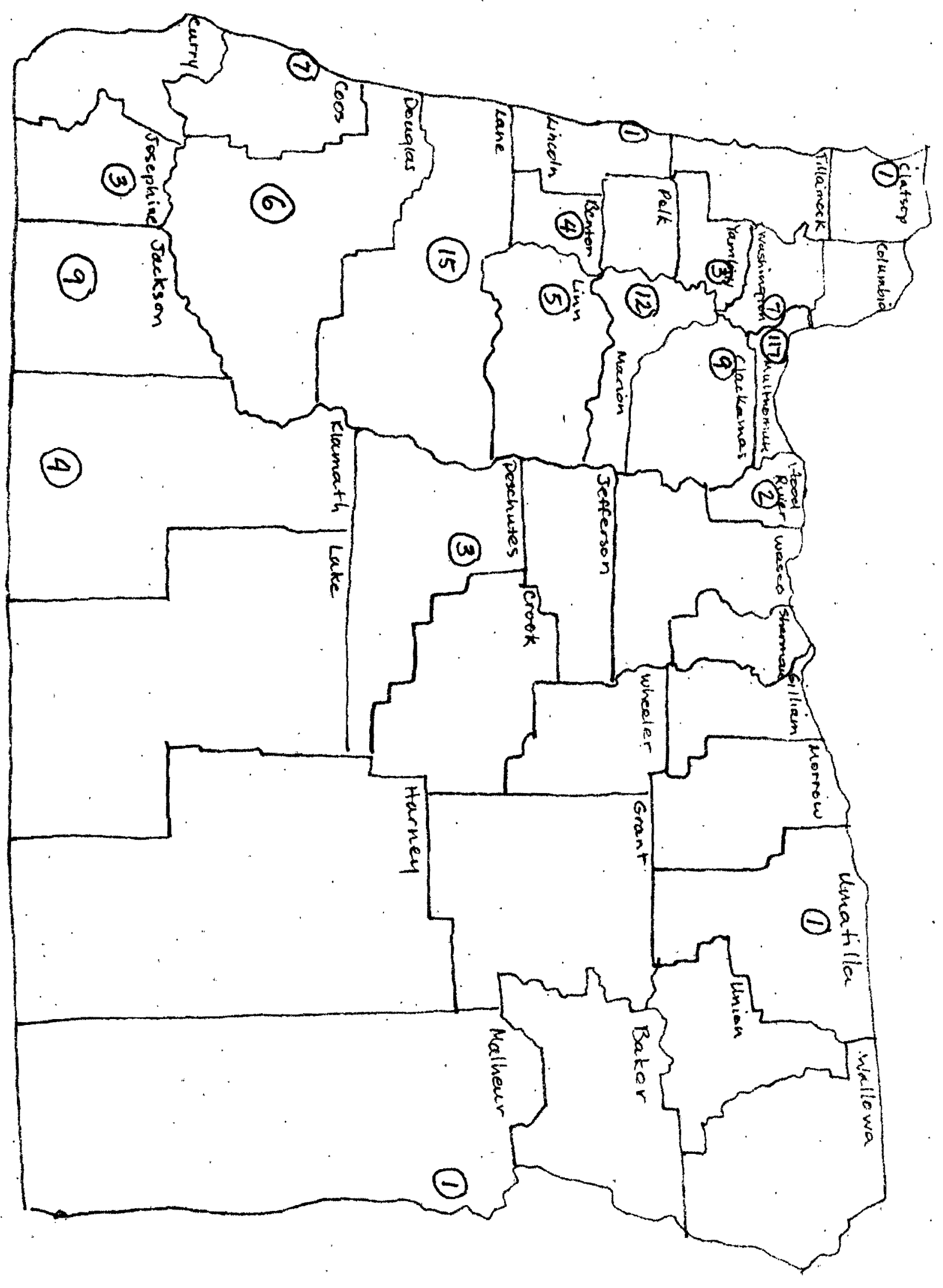


MENTAL, HEALTH

HEIP!

FOR

CHILDREN

Route 2, Box 388

Aurora, Oregon 97002

January 15,1976

Dear Dr.

Enclosed you will find a questionnaire relating to mental health services for children in the State of Oregon. This questionnaire was designed specifically to meet part of the requirements for a Master's Degree in Soclal Work, but more importantly, perhaps, It was designed with the hopes that it would contribute to the overall effort to improve both the planning and the funding of mental health programs for children which will come up for cons1deration in the next session of the Oregon Legislature.

As a member of the pediatric profession, you were chosen as a respondent because it was felt that your commitment to the welfare of children would be global and that your interest in the mental health of children would be great. Of the many professional categories considered, it was felt that your profession could contribute uniquely in helping us to discover the resources that currently exist for children in this state and--ultimately--what resources need to be developed.

Your help in completing this questionnaire will not only be an enormous help to me in my program of study, but will be a contribution to the effort to move ahead in the develop of mental health resources for chlldren.

I would like to emphasize the fact that the results of these questionnaires will be held strictly confidential, and if you prefer, there is no need for you to put your name on $1 \mathrm{t}$.

Yours sincerely,

Kristin Angel1

Master's Candidate

Portland State University

School of Social Work 
$X$ XIanadd 
QUESTIONNAIRE

January, 1976

COUNTY OR COUNTIES YOU SERVE

PRACTICE PRIMARILY METROPOLITAN

? OR RURAL $?$

YEARS IN PRACTICE AS A PEDIATRICIAN

AGE SEX

LIST ANY SUBSPECIALTY

1. The children you see come to you with many kinds of problems. Some of them are physiological, some of them are social, and some of them are mental or emotional. of the children you've seen in the past six months, approximately what percentage do you believe have mental or emotional problems (such as unusual fears, high anxlety, withdrawa1, hallucinatiors, difflculties in concentration, extreme passivity, etc.)

(Check the approprlate box.)

$: 0-10 \%: 10-20 \%: 20-30 \%: 40-50 \%: 50-60 \%: 60-70 \%: 70-80 \%, 80-90 \%$ 5 yrs.

5-9 yrs.

10-14yrs

2. If possible, estimate the total number of children with these problems you've seen within the past six months.

3. Which age group are most in need of services? 
4. Of those chlidren you have identified as having mental or emotional problems:

a. To what percentage do you provide primary treatment for their mental or emotional disturbance?

b. What percentage do you refer to another treatment source __ ?

c. What percentage do you neither treat nor refer?

TOTAL.............100\%

5. Do you utilize consultative services from Mental Health professionals in your treatment of these children?

a. If not, give reason:

b. If you do use such services, which agency or profession do you primarily use?

c. Do you feel that more mental health consultation services need to be made available?

(CONTINUE TO NEXT PAGE) 
6. Of those patients you refer to other treatment resources, what resources do you currently utilize? Please check the appropriate box for each of the following resources 1 isted and fill in any additional resources which you use at the bottom.

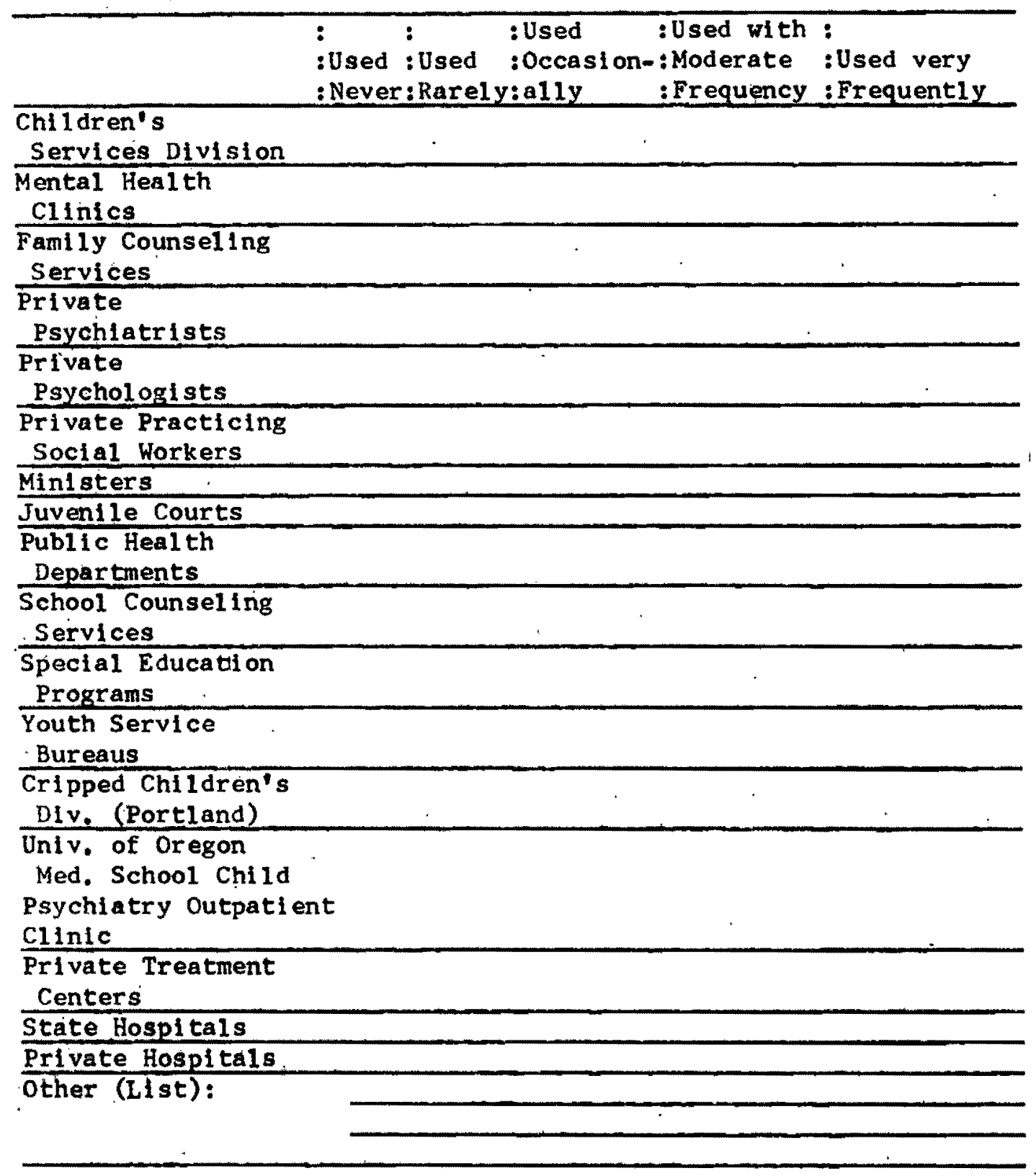


7. In planning and developing services for children, it would be helpful to know about your satisfaction with the resources which you use. This satisfaction ma relate to the quantity of the resources, (Are there enough of them?) or to the quality of the resources. (Are you satisfled with the services provided by this resource?) In the following chart, check the approprlate box which best describes your level of satisfaction with the resource 11 sted.

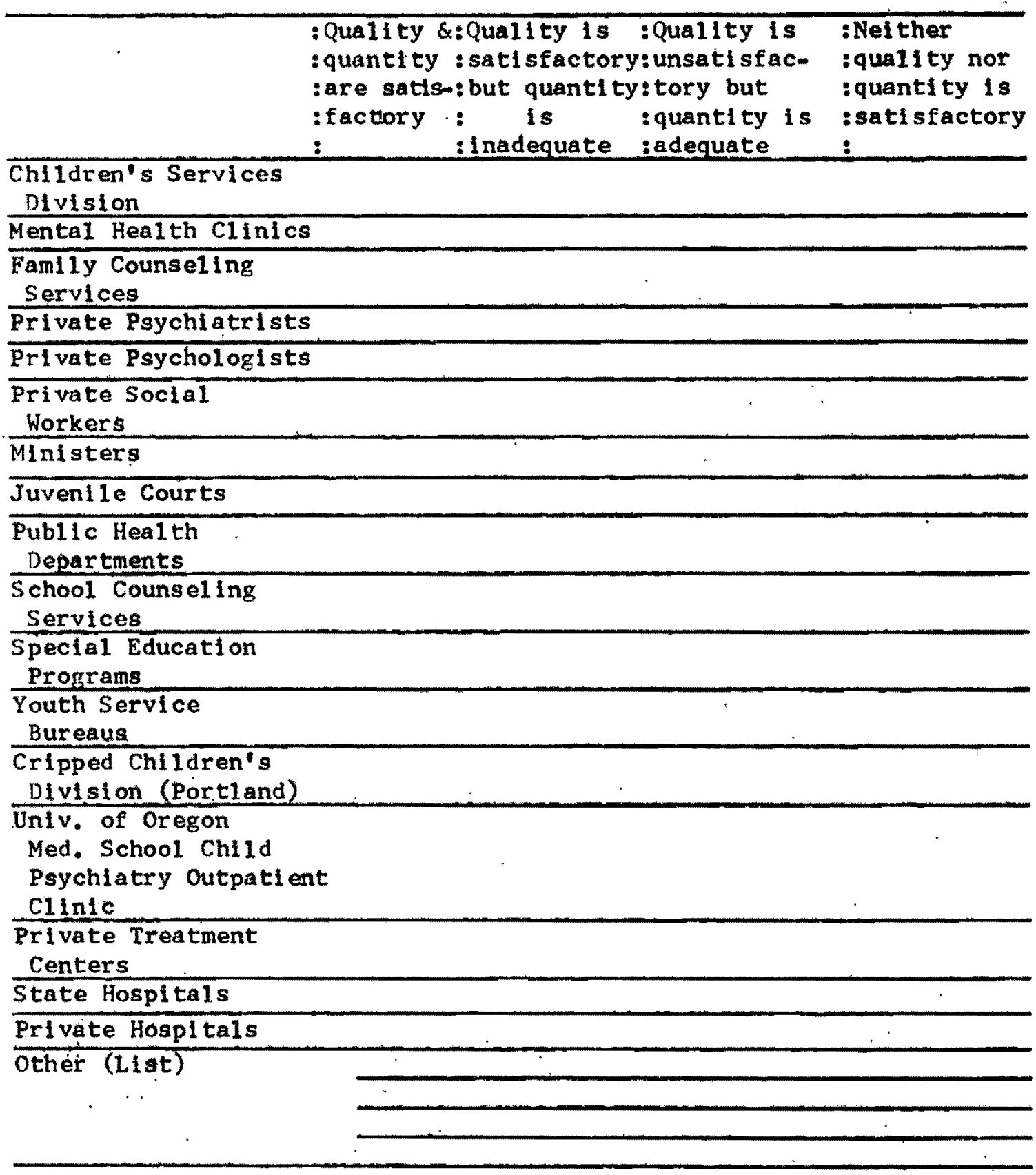


8. Some people feel that all of the needed services for children are not offered by currently existing agencles. What mental health resources or services for children do you belleve are most needed in your area of the state?

9. Sometimes planning for speclalized services for children varies between the local and the state level. Do you have any suggestions for the Improvement of Mental Health Servides to children at the state level?

10. Do you have any other suggestions for the improvement of Mental Health Services to children?

11. If one of your own children were suffering from a mental or emotional disturbance, where would you take him? 

Route 2; Box 388

Aurora, Oregon 97002

May 28, 1976

Department of Pediatrics

University of Oregon Health Sclences Center.

3181 SW Sam Jackson Park Road

Portland, Oregon

Dear Dr. Cohen:

I am currently engaged in a research study as a part of the requirements for an M.S.W. degree taken from Portland State University. While the study wlll touch upon several areas of the mental health service dellvery system for chlldren in the State of Oregon, its primary focus will be upon the role of the pediatrician within this total system.

As one way of looking at how pediatricians relate both to the problem of the emotionally disturbed child and to the formal system whi ch is set up to provide care for such children, I am presently examining some of the ways in which the Department of Pediatrics at UoHSC approaches this entire area. Obviously, the way in which pediatric residents view the training program is an important part of the total picture.

The attached questionnaire does not represent a systematic effort to gather hard data about training programs. It is intended, rather, to give me an overall plcture which can aupplement some of the more stralghtforward Information which I've acquired about curriculum content and specific requirements of the training program. Rlease feel free, therefore, to write comments or to. enlarge upon any of the items which you might feel to be incomplete.

As a person in training, I have a profound appreclation for how overburdened your time is. I hope, however, that in splte of the many demands placed upon your time, you will be able to fill out this brief questionnire. The results will be held strictly confidential, and if you wish, there is no need to put your name on $1 t$.

Yours sincerely,

Kristin S. Angell

M.S.W. student 

1. During your years of residency training, did you choose any electives relating specifically to the diagnosis and treatment of mental and emotional disorders of childhood $?$

2. If the answer to No. 1 was yes, did you find that this part of your tralning was helpful?

3. Next to the following items, place an $X$ in the space to indicate whether you feel your training has included too 11 ttle, too much, or the right amount of material in the areas described. This might include clinical contacts, special seminars, content of supervision, etc.

$$
\begin{array}{ll}
\text { too too } & \\
\text { little much enough }
\end{array}
$$

a. Normal psychological development of children

b. Diagnosis of major psychological disturbances of childhood

c. Management and treatment of the child with psychological disturbance

d. Use of consultative services and referrals to mental health resources

4. Place an $X$ in the space beside the statement which you feel best describes the prevaling attitude of members of the pediatric department. place a $Y$ in the second space next to the statement which best describes your own attitude.

a. In most cases of mental and emotional

Staff

Atti tudes disorders of children, pediatricians could provide primary treatment if they utilized consultation services from mental health professionals.

b. Pediatriclans should be qualified to handle mild behavior problems of childhood but should refer all serious mental and emotional disturbances to a qualified mental heal th specialist.

c. Pediatricians have been stepping over thelr boundarles in trying to be all things to all people. The business of a pediatrician should be to treat the physical problems of children. Any problems which are not physical should be referred to a psychiatrist or other mental health specialist.

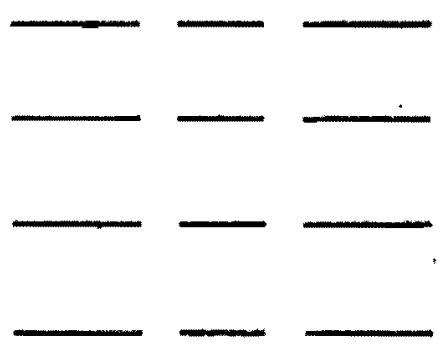

Your own Atti tude 
d. Pediatriclans have been trying to ignore the mental and emotional problems of

childhood for too. long. They need more training to help them make accurate diagnoses and intelligent referrals when they are unable to provide treatment themselves.

e. Pediatriclans should be prepared to handie short term, acute psychiatric crises in children, such as those frequently found in an inpatient setting, but should refer all cases requiring long term treatment to a mental health specialist.

Year. in which residency w11 be completed 


\section{A LIST OF WORKS CONSULTED}

1. American Academy of Pediatrics, Child Heelth Services in Oregon, Published under Auspices of Oregon State Board of Health, State Printing Department, June 1948.

2. Bevilacqua, Joseph J., Director, "Position Sta tement on the Planning of Mental Health Services for the Children \& Youth of Rhode Island," (Unpublished Report), Dept. of Mental Health, Retard. \& Hospitals, Div. of Mental Health, January 1975.

3. Borensteln, Henry, Profect Director, L.A., "Admisstons Systems of Residential Care Faclitities for Chlldren and Adolescents in L.A. County," Children \& Youth Commlttee, Mental Health Development Committee, 1974.

4. Child Study and Treatment Section, Children's Services Division, Department of Human Resources, "Report of Activitles," (Unpub11 shed Report), March 1973.

5. East, Allan, Child Guidance Clinics in Small Communitles of Oregon, University of Oregon Medical School, Portland, Oregon, 1939.

6. Finch, Stuart and McDermott, John F., Jr., Psychlatry for the Pediatrician, W.W. Norton \& Co., Inc., New York, 1970.

7. Ganser, Leonard, "Position of NASMHP on Developmental Needs of Ch1ldren," NASMHPD, Sept. 8, 1970.

8. Goldstein \& Maluccio, "The Emotionally Disturbed Child.and the Communities' Response," Special Interdepartmental Task Force, State of Rhode Island, Dec. 1970.

9. Group for the Advancement of Psychlatry, "The Contribution of Child Psychiatry to Pediatric Training and Practice," Report No. 21, January 1952.

10. Group for the Advancement of Psychiatry, "Crisis in Child Mental Heal th: A Critical Assessment," Report No, 21, February 1972 .

11. Group for the Advancement of Psychiatry, "From Diagnosis to Treatment: An Approach to Treatment Planning for the Emotionally Disturbed Child," Vol. VIII, Report No. 87, September 1973.

12. Joint Comission on Mental Health of Children, Inc., Crisis in Chlld Mental Heal th: Challenge for the 1970's, New York, 1970.

13. Joint Commission on Mental Health of Children, Inc., "Interim Report," Chevy Chase, Md., June 1968. 
14. Kirkpatric, Milton, "A Study of Child Guidance Services in Portland and the State of Oregon with Special Reference to Ways in Which They May be Improved," Portland, 193_.

15. Krakowsk1, Adam J. and Santora, Dante A., Child Psychiatry and the General Practitioner, Springfield, I11 inois, 1962.

16. League of Women Voters, Mental Health Services for Children and Youth in Oregon," Resource Committee Materlal, Part I and II, Salem, Oregon, September 1974.

17. Letz, Fred, Director, Mental health Division, "Proposal of a Chlldren's Program," Unpublished Report to subcommlttee on Services to Emotlonally Disturbed Children, Salem, Oregon, June 21, 1970.

18. Lewis, Martin C., "Description of the Child Guidance Cilnic Set-up and Suggested Expansion," Portland, Oregon, 1936.

19. Mckinnon, Archie et al, "The Child Guidance Clinic, Catalyst and Co-ordinator in Community Treatment of the Psychotic Child," Community Mental Health Journal, Vol. 4 (4). 307-313, 1968.

20. Maluccio, Anthony N., "Residentlal Treatnent of Disturbed Chi1dren: A Study of Service Delivery," Child Welfare, Vol. IIII, No. 4, 225-235, Apr11 1974.

21. Maluccio, Anthony N. Marlow, WIIma D., "Residential Treatment of Emotionally Disturbed Children: A Review of the Literature," The Social Service Revi ew, Vol. 46, No, 2, June 1972.

22. Mental Health Planning Board for the Mental Health Division of the Oregon State Board of Control, The U1timate Goal: A Plan for Today A Comprehensive Plan for a Mental Health Program in Oregon, 1965.

23. Mental Health Research Unit, New York State Department of Mental Hygl ene, "Elementary School Children with Persistent Emotional Disturbances, A Summary Report of a Study in Onandaga County, N.Y.," Albany, N.Y., December 1974.

24. National Institute of Mental Health, Office of the Director, "Mental Health of Children, The Chlld Program of the National Institute of Mental Health," Bethesda, Maryland, December 1965.

25. Oregon Division of Mental Health, Bureau of Health, "First Report: A Proposed Mental Health Program for the Public Schools," Portland, Oregon, August 1955.

26. Oregon Governor's Child Welfare Study Committee, Chlld Welfare Needs and Services in Oregon, Greenlelgh Assoclates, Inc., New York, December 1968. 
27. Oregon Governor's Comittee, Oregon's White House Conference on Child Health and Protection, Salem, Oregon, May 1932.

28. Oregon Governor's Committee on Children and Youth, Focus on Children: The Signiflcant First Decade, Proceedings of the 1966 Oregon Conference on Children and Youth, Salem, Oregon, December 1966.

29. Oregon Governor's Committee on Youth, Mental Health Assoclation. of Oregon, Recommendations of Professional Study Group on Report of the Joint Commi ssion on Mental Health of Children, Inc., (Unpubl Ished Report), Apr11 21, 1970.

30. Oregon Governor's State Comml ttee on Chll dren and Youth, Health Services \& Faclilties for Children in Oregon, Portiand, Oregon, 1952.

31. Oregon Governor's State Committee on Chl1dren and Youth, Mental Health Services for Children and Youth in Oregon, Portiand, Oregon, 1950.

32. Oregon Mental Health Division, Compilation of Data on Childmen: Annual Report; Community Mental Health Programs, Sal em, Oregon, 1973-74.

33. Oregon Mental Health Division, Children's Services Section, Mental Health Program for Children, House B111 1869. Oregon Mental Heal th Division $1971-73$ Budget Request. Decenber 1, 1970.

34. Oregon Mental Heal th Division, Department of Human Resources, 1973 - A Turning Polnt for Mental Heal th Programs in Oregon, State of Oregon, October 1, 1973.

35. Oregon Mental Health Division, Draft of Purchase Care Program Psychiatric Services for Children, (Unpublished Report), Apr11 1967.

36. Oregon Mental Heal th Division, Northwest Reglonal Forum on Mental Health Services for Children, Portiand, Oregon, Septeaber 1975.

37. Oregon Mental Health Division, Oregon Revlsed Statutes Relating to Mental Health, Salem, Oregon, June 1974.

38. Oregon Mental Heal th Division, Pilot Progran for Emotionally Dl sturbed Chlidren, (Unpublished Report), Salen, Oregon, February 1969.

39. Oregon Mental Health Division, Review of Mental Health Division Programs, (Unpubli shed Report), December 15, 1966. 
40. Portland City Club Foundation, Inc., Report on Services for Severely Disturbed Children in Oregon, Vol. 51, 10.42 , March 19, 1971.

41. Schulman, Jerome S., Management of Emotional Di sorders in Pedlatric Practice, Year Book Medical Publisherd, Inc., Chicago 1969.

42. Shirely, Hale F., Psychlatry for the Pediatriclan, oxford University Press, New York, 1948.

43. Shore, James, Director, "Consul tation Report on County Mental Health P1an," (Unpubl ished Report), September 30, 1974.

44. Task Force on the Mental Heal th of Children, State of Maine, Comprehensive Paln for Mental Health suevices to Children, Department of Mental Health and Corrections, July 1974.

45. Taylor, Eugene August, "Needed Services for Severely Emotionally Disturbed Children in Oregon," Unpublished report to the Mental Health Planning Board, 1964.

46. Treleaven, J.H., "A Residential Care Program for Chlldren and Adolescents with Severe Mental Illness," Monograph, Apri1 13, 1966.

47. Turnibul1, George, Editor, Oregon Governor's State Committee on Children \& Youth, A Look at Oregon's Children: Report to the Golden Anniversary hit te House Conferience on Child ten \& Youth, Salem, Oregon, November 1959.

48. University of Oregon Medical School, A Plan for the Extension of the Child Guldance Ciinic of the University of Orezon Medical School to Communt ties in the Stete of Oregon, November 1936.

49. University of Oregon Medtcal School, Child Guldance in Oregon: with Recommendations of the Governor's Special Comittee, State Child Guidance Program, July 1, 1937.

50. University of Oregon Medical School, Annual Reports: 1937-38 -1947-48, Child Guldance Clinic Extension, Portland, Oregon.

51. White House Conference Committees, Needed Services for Oragon's Chlldren: A Summary of Reports, Sal en, Oregon, 1959.

52. Woodcock, Oma; The Nature and Source of Referrals to the Child Guidance CIInici Reed College, Portland, Oregon, 1938.

53. No author 1isted, "Statistical Study of the State Chld Guidance Extension Progran of the Unlversity of Oregon Medical School," Portland, Oregon, January 1939. 